\title{
Particle number size distributions in urban air before and after volatilisation
}

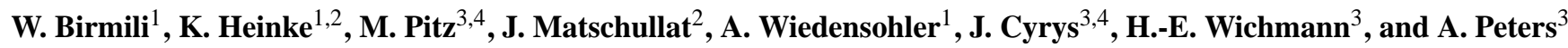 \\ ${ }^{1}$ Leibniz Institute for Tropospheric Research (IfT), Permoserstrasse 15, 04318 Leipzig, Germany \\ ${ }^{2}$ Interdisciplinary Environmental Research Centre (IÖZ), TU Bergakademie Freiberg, 09599 Freiberg, Germany \\ ${ }^{3}$ Helmholtz Zentrum München (HMGU), German Research Center for Environment Health, Institute of Epidemiology, \\ 85758 Neuherberg/Munich, Germany \\ ${ }^{4}$ University of Augsburg, Center for Science and Environment, 86159 Augsburg, Germany
}

Received: 25 February 2009 - Published in Atmos. Chem. Phys. Discuss.: 7 April 2009

Revised: 12 May 2010 - Accepted: 14 May 2010 - Published: 21 May 2010

\begin{abstract}
Aerosol particle number size distributions (size range $0.003-10 \mu \mathrm{m}$ ) in the urban atmosphere of Augsburg (Germany) were examined with respect to the governing anthropogenic sources and meteorological factors. The twoyear average particle number concentration between November 2004 and November 2006 was $12200 \mathrm{~cm}^{-3}$, i.e. similar to previous observations in other European cities. A seasonal analysis yielded twice the total particle number concentrations in winter as compared to summer as consequence of more frequent inversion situations and enhanced particulate emissions. The diurnal variations of particle number were shaped by a remarkable maximum in the morning during the peak traffic hours. After a mid-day decrease along with the onset of vertical mixing, an evening concentration maximum could frequently be observed, suggesting a re-stratification of the urban atmosphere. Overall, the mixed layer height turned out to be the most influential meteorological parameter on the particle size distribution. Its influence was even greater than that of the geographical origin of the prevailing synoptic-scale air mass.

Size distributions below $0.8 \mu \mathrm{m}$ were also measured downstream of a thermodenuder (temperature: $300^{\circ} \mathrm{C}$ ), allowing to retrieve the volume concentration of non-volatile compounds. The balance of particle number upstream and downstream of the thermodenuder suggests that practically all particles $>12 \mathrm{~nm}$ contain a non-volatile core while additional nucleation of particles smaller than $6 \mathrm{~nm}$ could be ob-
\end{abstract}

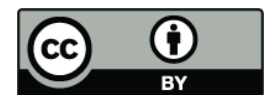

Correspondence to: W. Birmili (birmili@tropos.de) served after the thermodenuder as an interfering artifact of the method. The good correlation between the non-volatile volume concentration and an independent measurement of the aerosol absorption coefficient $\left(R^{2}=0.9\right)$ suggests a close correspondence of the refractory and light-absorbing particle fractions. Using the "summation method", an average diameter ratio of particles before and after volatilisation could be determined as a function of particle size. The results indicated that particles $>60 \mathrm{~nm}$ contain a significantly higher fraction of non-volatile compounds, most likely black carbon, than particles $<60 \mathrm{~nm}$. The results are relevant for future health-related studies in that they explore the size distribution and time-dependent behaviour of the refractory component of the urban aerosol over an extended time period.

\section{Introduction}

Atmospheric particles (particulate matter, PM), particularly such of anthropogenic origin, have been associated with adverse health effects in humans (e.g., Pope and Dockery, 2006; WHO, 2004, 2006). To reduce the number of premature deaths and disease caused by particulate air pollution, legal limit values have been implemented in the European Union, thus regulating the total mass concentration of particles with diameter less than $10 \mu \mathrm{m}$ (EC, 1999). However, the health risk due to environmental particle exposure is probably not an effect of total particle mass but more likely of a combination of specific, more toxic sub-fractions (HEI, 2002; Sioutas et al., 2005). Identification of the more hazardous sub-fractions of the aerosol would permit abatement

Published by Copernicus Publications on behalf of the European Geosciences Union. 
measures that are beneficial for public health. Legal measures to reduce ambient PM levels could be designed more cost-effectively if they were targetted on the abatement of specific particle types rather than the total PM mass.

Several particle types have been proposed to be associated with adverse health effects. Ultrafine particles (UFPs, diameter $<100 \mathrm{~nm}$ ), for example, have been suggested to act more toxically after inhalation than bigger particles (Wichmann and Peters, 2000; von Klot et al., 2005; Oberdörster et al., 2005). Due to their small size, UFPs can penetrate more deeply into the alveolar region, and also contain a higher mass-specific particle surface area, which is the interface where particles interact with the human organism. Other lines of argument have pointed to the overwhelming carbonaceous character of atmospheric UFPs: Insoluble UFPs, such as originating from anthropogenic high-temperature combustion, have a high possibility to deposit in alveolar spaces and subsequently translocate into their interstitial spaces and later to other organ systems (Möller et al., 2008). A link to respiratory and cardiovascular disease has been suggested (Kreyling and Scheuch, 2000; Schwarze et al., 2006). Other reported risk factors are related to the biological surface reactivity, as well as specific (bio-)chemical compounds as distinct as transition metals and endotoxins. Concluding from the above discussion, a more specific physical and chemical aerosol characterisation would be desirable for both, specialised health-related studies as well as government monitoring networks.

One useful parameter is the particle number size distribution, from which various parameters such as the number of ultrafine particles can be derived, and the particle surface area can be estimated. Long-term measurements of ambient particle size distributions have been scarce until recently, but the body of reports on such measurements is augmenting. Ambient size distribution measurements have revealed that the engine exhaust of motor vehicles releases enormous numbers of particles into the vicinity of urban roads (Hitchins et al., 2000; Wehner et al., 2002a; Charron and Harrison, 2003; Ketzel et al., 2003; Zhu et al., 2004; Voigtländer et al., 2006) or motorways (Zhu et al., 2004; Rosenbohm et al., 2005; Imhof et al., 2005; Birmili et al., 2009a). In cities where motor traffic is the dominating source of anthropogenic particles, the particle size distribution at urban background sites shows an attenuated image of the daily traffic cycle (Ebelt et al., 2001; Kreyling et al., 2003; Wehner and Wiedensohler, 2003; van Dingenen et al., 2004; Hussein et al., 2004; Ketzel et al., 2004; Aalto et al., 2005). In the presence of solar radiation, the total particle number in urban areas is also influenced by photochemically-induced secondary formation (Kulmala et al., 2004; Costabile et al., 2009).

Volatility analysis has been developed as a technique to discriminate classes of chemical compounds in airborne particles by their different degree of volatility. Previous research has been particularly directed towards differentiating between, for instance, sulphuric acid, neutralised sulphate, sodium chloride, and elemental carbon (Clarke, 1991; Smith and O'Dowd, 1996; Kreidenweis et al., 1998; Schmid et al., 2002). Thermodenuders are widely used as conditioning devices in which volatile compounds are stripped off the particles while these remain airborne (Burtscher et al., 2001). Recently, the design of thermodenuders has been improved with respect to efficient vapour removal (Wehner et al., 2002b; Fierz et al., 2007), short transit time (An et al., 2007), and rapid response towards temperature changes (Huffman et al., 2008).

In the polluted atmosphere, particulate emissions of diesel vehicles exhibit a soot particle mode with diameters around $80 \mathrm{~nm}$, and a smaller nucleation mode originating from recondensation of unburnt fuels (Ntziachristos et al., 2004). While the diesel soot mode is rather non-volatile at temperatures of $300^{\circ} \mathrm{C}$, the condensation mode is composed mainly of long-chained organics volatile above $100^{\circ} \mathrm{C}$ (Sakurai et al., 2003). Measurements with volatility analysers (Philippin et al., 2004; Rose et al., 2006) or thermodenuders in conjunction with particle mobility spectrometers (Hasegawa et al., 2004) have confirmed the ubiquity of traffic-derived soot particles in the proximity of highly trafficked roads. In a street canyon in Leipzig, for example, the number fraction of externally mixed soot particles was concluded to amount to $60 \%$ compared to $6 \%$ at a rural reference station (Rose et al., 2006). Besides, thermodenuder/mobility spectrometer combinations have also been used to examine nucleation mode particles evolving from photochemically-induced secondary formation (Wehner et al., 2005; Ehn et al., 2007). The latter works suggested that even freshly nucleated particles during to photochemical processes contain a core that is non-volatile at $300^{\circ} \mathrm{C}$.

The aim of this work was to quantify and discuss particle number size distributions and their non-volatile components in the city of Augsburg, southern Germany. Particular interest in Augsburg derives from the interdisciplinary research platform KORA (Kooperative Gesundheitsforschung in der Region Augsburg - cooperative health research in the Augsburg region), which was established as early as 1984 (Holle et al., 2005). A comprehensive body of epidemiological studies within KORA has suggested a link between air pollution and cardiovascular diseases, but also revealed the need of a more detailed characterization of air pollutants, notably the physical and chemical properties of airborne particles and their temporal variability (Peters et al., 2005; von Klot et al., 2005). Within KORA, particular efforts are directed towards identifying the health-relevant sub-fractions in the ambient aerosol.

This study aims at establishing the basic characteristics of long-term particle size distribution observations (0.003$10 \mu \mathrm{m})$ in Augsburg, with emphasis on the non-volatile components measured downstream of a thermodenuder. In the sub- $\mu \mathrm{m}$ range, the non-volatile fraction has broadly been associated with black carbon, although other particle types, 
such as mineral dust or biological particles are admitted to contribute to the non-volatile fraction as well. Using local meteorological parameters as well as back trajectory calculations, the study provides an assessment of the climatologically relevant processes that control the environmental aerosol in Augsburg.

\section{Experimental}

\subsection{Sampling site}

In November 2004, the Helmholtz Zentrum München (HMGU) started particle number size distribution measurements at an urban background monitoring station in Augsburg. The HMGU monitoring station is located at an urban background setting on premises of Augsburg's University of Applied Sciences (Fachhochschule Augsburg) (48 $22^{\prime} \mathrm{N}$; $\left.10^{\circ} 54^{\prime} \mathrm{E}\right)$. The station is located about $1 \mathrm{~km}$ south of Augsburg's city centre with the nearest street being about $100 \mathrm{~m}$ north-east of the site (Fig. 1). Spatially resolved measurements of total particle number suggested this site of being representative of urban background conditions (Cyrys et al., 2008). Additional details of the site have been reported by Pitz et al. (2008a). The HMGU station is also a member of the German Ultrafine Aerosol Network (GUAN), designed at monitoring health-related properties of the environmental aerosol in Germany (Birmili et al., 2009b).

\subsection{Instrumentation}

Particle number size distributions in a diameter $\left(D_{p}\right)$ range 3-800 nm were measured using a flow-regulated twin differential mobility particle sizer (TDMPS). This instrument is based on two differential mobility analysers covering complementary size ranges (Birmili et al., 1999). Briefly, the first subsystem combines an ultrafine Vienna-type differential mobility analyzer (electrode length $11 \mathrm{~cm}$ ) with an ultrafine condensation particle counter (UCPC model 3025, TSI Inc., Shoreview (MN), USA) to measure particles across a range from 3 to $23 \mathrm{~nm}$. The second subsystem combines another differential mobility analyzer (electrode length $28 \mathrm{~cm}$ ) with a condensation particle counter (CPC model 3010, TSI Inc.) to measure particles between 18 and $800 \mathrm{~nm}$. The sheath air is circulated in a closed loop, at relative humidities ranging mostly between 10 and $30 \%$.

Upstream of the TDMPS, a thermodenuder (TD) was deployed as an option to remove volatile aerosol components. Our TD follows the design of Wehner et al. (2002b). Volatile particle material is evaporated at a temperature of $300^{\circ} \mathrm{C}$, and subsequently removed with the assistance of active carbon in a cooling section. The temperature of $300^{\circ} \mathrm{C}$ was selected with the aim of evaporating the overwhelming fraction of inorganic ions - particularly ammonium sulfate and nitrate, although not sodium chloride as well as most organic

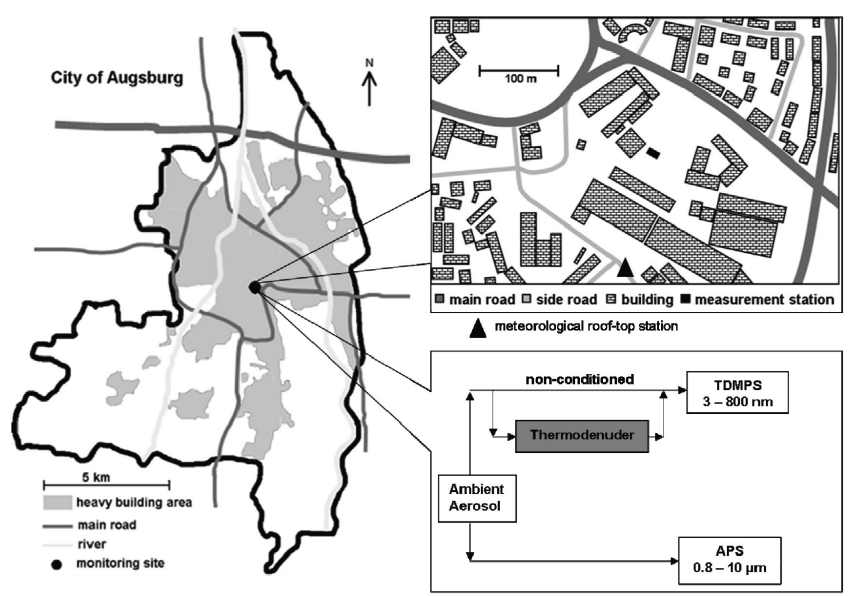

Fig. 1. Regional map of Augsburg, Germany, including the detailed surroundings of the HMGU monitoring station. The lower inset illustrates the concurrent measurement of TDMPS and APS size distributions with the option of using a thermodenuder upstream the TDMPS.

carbon from the particle phase ${ }^{1}$. On the other hand, $300^{\circ} \mathrm{C}$ is a temperature at which charring ${ }^{2}$ of organic compounds is avoided.

The standard operation procedure for the TDMPS was to record size distributions upstream and downstream of the TD in alternating sampling intervals of $10 \mathrm{~min}$ (cf. inset in Fig. 1). This procedure provided a steady flow of size distributions both with and without the TD, and an overall time resolution of $20 \mathrm{~min}$ for each of these measurement modes. Before further data analysis, the size distribution data was averaged to hourly values.

In the TD, the aerosol sample is subject to enhanced particle losses. One can think of, e.g., diffusional as well as thermophoretic losses, which are both a function of particle size. Prior to the field experiment, these particle losses were quantified in the laboratory using spherical silver particles (solid at $300^{\circ} \mathrm{C}$ ), and by measuring the particle counts upstream and downstream of the TD. The penetration of solid particles through the heated thermodenuder was about 0.34 at $3 \mathrm{~nm}$, 0.66 at $10 \mathrm{~nm}$ and 0.85 for particles bigger than $100 \mathrm{~nm}$. All TD number size distributions shown in this work were corrected for these particle losses.

Occasionally, extreme concentrations of particles with diameters less than $6 \mathrm{~nm}$ were observed downstream of the $\mathrm{TD}$, which were identified as the re-nucleation of gas-phase species in the cooling section of the TD due to incomplete re-

\footnotetext{
${ }^{1}$ Ammonium nitrate and ammonium sulphate are reported to have volatilisation temperatures of ca. 75 and $202^{\circ} \mathrm{C}$, respectively (Pinnick et al., 1987; Johnson et al., 2004). Engler et al. (2007) (Table 1) provides a brief overview of known volatilisation temperatures.

${ }^{2}$ Charring is the incomplete combustion of (oxygenated) hydrocarbons removing hydrogen and oxygen, and leaving pure carbon.
} 
moval of volatilized material. This operational artifact could not be completely eliminated. Figure 2 gives an illustration of its effect on total particle number concentration. In some cases, the total particle number concentration downstream of the TD may largely exceed the concentration upstream. When ignoring size channels below $7 \mathrm{~nm}$, however, the particle number balance across the thermodenuder becomes approximately unity. The nucleation effect disappears completely when truncating the distribution downstream of the TD at $10 \mathrm{~nm}$.

The instrumentation also contains an aerodynamic particle sizer (APS model 3321, TSI Inc.) which measures aerodynamic size distributions of ambient particles between 0.8 and $10 \mu \mathrm{m}$. We refrained from connecting the APS to the TD because of the considerable length of tubing associated with the thermodenuder; this would lead to considerable sampling losses of the super- $\mu \mathrm{m}$ particles. Additional measurements involve gravimetric $\mathrm{PM}_{2.5}$ and $\mathrm{PM}_{10}$ mass concentrations using a tapered element oscillating microbalances (TEOM) equipped with a filter dynamics measurement system.

Mass concentrations of black carbon (BC) were determined using an aethalometer (Type 8100, Thermo Fisher Scientific Inc.). The aethalometer converts light attenuation through a particle-laden quartz fiber filter into $\mathrm{BC}$ mass concentration using the experimentally determined specific attenuation cross-section of $16.6 \mathrm{~m}^{2} \mathrm{~g}^{-1}$ at a wavelength of $880 \mathrm{~nm}$. To validate the aethalometer's performance, we compared the instrument in Augsburg during one month (9 September-8 October 2008) against a high quality reference instrument, the multi-angle absorption photometer (MAAP; see Petzold and Schönlinner, 2004; Petzold et al., 2005). The intercomparison suggested that the aethalometer values are biased by a value around $+0.3 \mu \mathrm{g} \mathrm{m}^{-3}$ at the zero end, while the mean concentration during the period was matched rather

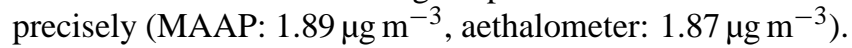
The exact relation to determine standardised (i.e. MAAPbased) black carbon concentrations from the aethalometer is as follows:

$\mathrm{BC}_{\mathrm{MAAP}}=1.111 \cdot \mathrm{BC}_{\mathrm{aeth}}-0.18$

For aethalometer concentrations below $1.36 \mu \mathrm{g} \mathrm{m}^{-3}$, a squared fit represents the data more accurately:

$\mathrm{BC}_{\mathrm{MAAP}}=-0.033 \cdot \mathrm{BC}_{\mathrm{aeth}}^{2}+1.335 \cdot \mathrm{BC}_{\mathrm{aeth}}-0.43$

Both fits show a high measure of determinaton $\left(R^{2}\right)$ of 0.96 .

Finally, wind speed, wind direction, temperature, and relative humidity were collected continuously at the HMGU station, and at FH Augsburg's meteorological roof-top station $20 \mathrm{~m}$ above ground and distant at about $0.5 \mathrm{~km}$. While the winds at the HMGU station tend to be influenced by the surrounding buildings, the winds at the roof-top station are considered representative for the entire urban area.

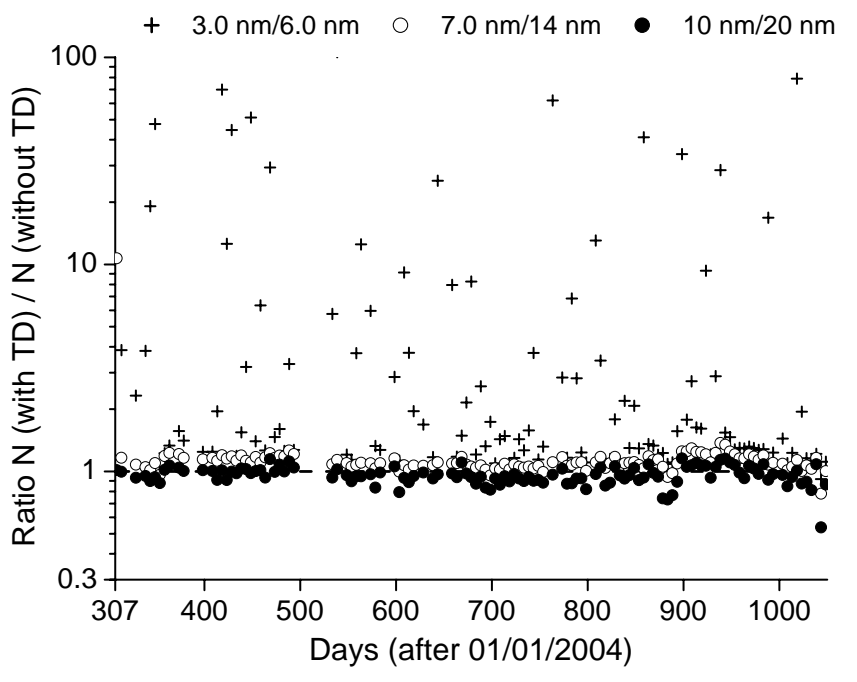

Fig. 2. Ratio between the total particle number concentrations upstream and downstream the thermodenuder. The labels indicate the pairs of lower threshold diameters that were applied to the nonconditioned and conditioned size distributions, respectively, before computing the integral number concentration. Time is coded in days after 01 January 2004. Plotted is every fifth daily average value of the measurement campaign.

\subsection{Size distribution evaluation}

TDMPS size distributions were evaluated according to the detailed description given by Pitz et al. (2008b). Briefly, the branches of both differential mobility analyser subsystems were assimilated into a single mobility distribution encompassing 3-800 nm. The mobility distributions were converted into size distributions using a multiple charge inversion, taking into account experimentally determined CPC and DMA transfer functions. Diffusional particle losses in the heated TD were corrected by a transmission function obtained from a laboratory calibration with silver particles between 3 and $50 \mathrm{~nm}$ in size. TDMPS and APS size distributions were combined into a single size distribution between 3 and $10000 \mathrm{~nm}$ assuming an effective density of $1.7 \mathrm{~g} \mathrm{~cm}^{-3}$ for the conversion of aerodynamic into mobility diameters. Pitz et al. (2008b) obtained this particular value by matching TDMPS and APS size distributions in the overlap region between $800-900 \mathrm{~nm}$ in mobility diameter. Moreover, the value is within the uncertainty range of the effective density that reconciles TDMPS/APS volume size distributions with a gravimetric $\mathrm{PM}_{2.5}$ measurement $\left(1.5-1.8 \mathrm{~g} \mathrm{~cm}^{-3}\right.$; Pitz et al., 2008a).

\subsection{Autocorrelation analysis}

The time fluctuations of the size distribution data were examined by auto-correlation analysis. Auto-correlation is the cross-correlation of a time-dependent signal with itself, and allows to identify periodical patterns that may, at first glance, 
be obscured by other confounding variables. The autocorrelation of environmental time series has been analysed to conclude on the time scales of variation of meteorological parameters (Wigley et al., 1998), but also tropospheric aerosols in marine (Heintzenberg et al., 2004), continental (Sunder Raman et al., 2008), and urban (Wehner and Wiedensohler, 2003) observation sites.

The auto-correlation function (ACF) was calculated as

$r_{x x}(\tau)=\frac{1}{n} \sum_{t=0}^{n} x(t) \cdot x(t+\tau)$,

with $x(t)$ being the standardised time series (zero mean, unit standard deviation) of particle number concentration.

\subsection{Diameter shrinking factors}

To relate the size distributions obtained with and without application of the TD, the summation method (SM) was used. The method was developed to quantify size-segregated diameter changes in particle size distributions caused by humidification (Birmili et al., 2009c), or thermodesorption (Engler et al., 2007). The SM assumes that the particle number size distribution is rearranged as a result of the aerosol conditioning. It associates segments of equal particle number concentration under the conditioned and non-conditioned size distributions - beginning at their upper tail, and continuing downwards. The ratio between the mean diameters of two corresponding particle number segments is the particle diameter shrinking factor (SF), concretely the fraction of their original diameter onto which particles collapse after passage through the TD. A detailed account on the numerical procedure is given in Birmili et al. (2009c).

An important prerequisite of the SM is that the total particle number is conserved during aerosol conditioning. Figure 2 shows the ratio between the respective experimental particle number concentrations downstream and upstream the thermodenuder. It is noteworthy that at certain times, new particles are observed to nucleate at the exit of the thermodenuder due to the cooling of vapours that have not been completely absorbed by the tube walls. This leads to ratios in the number concentration downstream/upstream the TD bigger than 1. This effect, which was found at a rural observation site as well during an earlier experiment (Fig. 4 in Engler et al., 2007), can lead to an overestimation of this number concentration ratio up to 100 .

To estimate the error induced by post-thermodenuder nucleation, different pairs of lower cut-off diameters ( 3 and $6 \mathrm{~nm}, 7$ and $14 \mathrm{~nm}$, and 10 and $20 \mathrm{~nm}$ ) were used to evaluate the sensitivity of this ratio on wether ignoring or not the lowest size channels, i.e. those actually affected by nucleation. Figure 2 suggests that total particle number concentration across the thermodenuder in Augsburg is conserved within the accuracy of measurement, as long as only unconditioned particles $>20 \mathrm{~nm}$ are considered.
A second prerequisite of the SM is that the external mixture of the sampled aerosol varies only slowly with particle diameter. A suitable tool for the verification of this prerequisite is the volatility tandem analyser method (e.g., Rose et al., 2006). In (Engler et al., 2007) we were able to establish that the diameter shrinking factors obtained by the SM indeed correspond to the shrinking behaviour of monodisperse particle populations selected by a volatility tandem analyser.

Limitations of the SM arise due to limited counting statistics at the upper tail of the size distribution, and due to the possibly incomplete recovery of particle losses occurring in the TD. As a consequence of both experiences, we limited the output range of the shrinking factors (SFs) to $30-300 \mathrm{~nm}$. Additional uncertainly derives from the non-simultaneity of the conditioned and non-conditioned size distribution measurements. This uncertainly was alleviated by first, using a spherical buffer volume (a 201 glass bulb) in the aerosol inlet system and second, by averaging size distributions to hourly values before applying the SM. It needs to be admitted that the buffer volume in the sampling caused additional particle losses. The particle penetration through the Augsburg buffer volume was not measured directly - only with a comparable device in the laboratory. The particle penetration was 0.45 at $10 \mathrm{~nm}, 0.93$ at $54 \mathrm{~nm}$ and roughly unity at particle diameters bigger than $100 \mathrm{~nm}$. Due to the uncertainty in determining the losses, we refrained from applying these corrections to the measurement data.

\subsection{Determination of the mixed layer height}

The mixed layer height (MLH) is the most important single meteorological parameter describing vertical air exchange and pollutant dispersal (Stull, 1988). For an estimate of the MLH we evaluated the nearest regular radiosounding data, recorded daily at 13:00 local time at $\mathrm{Mu}-$ nich/Oberschleissheim (50 km east of Augsburg). The MLH was derived from the pseudopotential temperature using the simple parcel method (Holzworth, 1964). The aerosol data in Augsburg were aggregated to a daily average covering the period between 12:00 and 18:00 LT, which captures essentially the daily minimum in Aitken and accumulation particle concentrations (cf. Fig. 5b-e below).

\subsection{Back trajectory cluster analysis}

A k-means cluster analysis combining 3d-back trajectories and vertical temperature profiles was applied to the entire dataset in close analogy to the work of Engler et al. (2007). The inclusion of vertical potential temperature profiles into the cluster analysis proved vital in understanding the reasons for high and low levels of particle number in Augsburg. The cluster algorithm divided the dataset into a predetermined number of 13 trajectory clusters. 6-day back trajectories were calculated for each day 13:00 UTC using the HYSPLIT model on the NOAA AR Ready Website (Draxler 


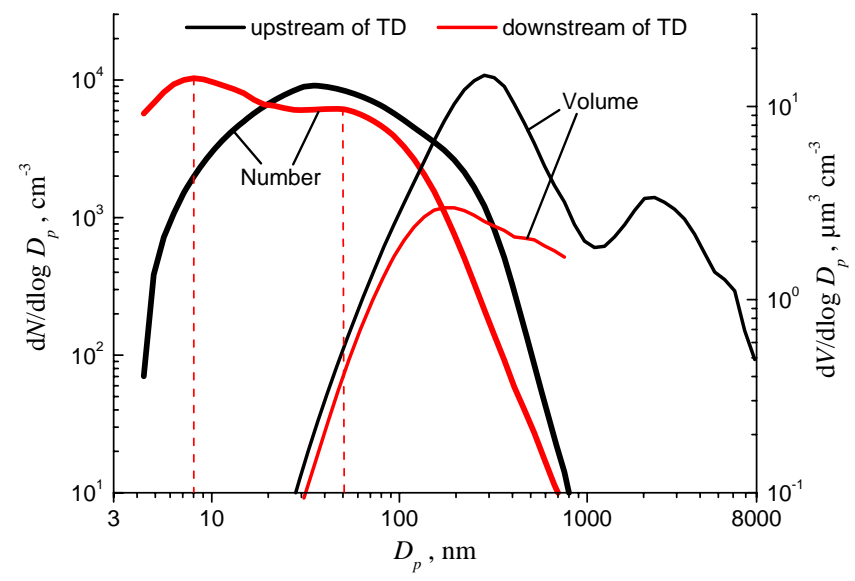

Fig. 3. Median number and volume size distributions of ambient (TDMPS/APS) and non-volatile (TDMPS with TD) particle concentrations in Augsburg between November 2004 and November 2006. Volume size distributions were calculated assuming spherical particles. Dashed lines mark the location of the two particles modes in the non-volatile distribution.

and Hess, 2004). Particle size distributions were averaged over the time interval 12:00-18:00 LT. According to the minimum concentrations observed in Fig. 5 below, that period represents best a homogeneously mixed boundary layer.

\section{Results and discussion}

\subsection{Non-conditioned particle data}

\subsubsection{Number concentrations and size distributions}

Figure 3 illustrates the median number and volume distributions in Augsburg for the entire 2-year period. The number distribution of particles upstream of the thermodenuder (TD) features a single maximum in the Aitken mode $(\sim 40 \mathrm{~nm})$, while the volume size distribution shows two peaks that mark the accumulation and coarse particle modes. The latter two modes are separated by a clear minimum around $1 \mu \mathrm{m}$. The passage through the TD modifies both distributions, and is discussed in detail in Sect. 3.2 below.

For a more accessible version of the data, the size distributions were integrated over six diameter intervals (see Table 1). It is worth noting that the boundaries of integration $(3,10,30,300,800,2000,10000 \mathrm{~nm})$ were chosen so that particle populations of a maximum statistical independence were generated (cf. auto-correlation analysis below).

The mean particle number concentration in Augsburg was $12000 \mathrm{~cm}^{-3}$ for the size range $3-10000 \mathrm{~nm}$ and the biennial period (sum of $\mu$ in Table 1), with the size interval 30-300 nm encompassing the majority of total particle number $\left(7600 \mathrm{~cm}^{-3}\right)$. The observed numbers are comparable with former observations of total particle number in Augsburg (Aalto et al., 2005), and range in the

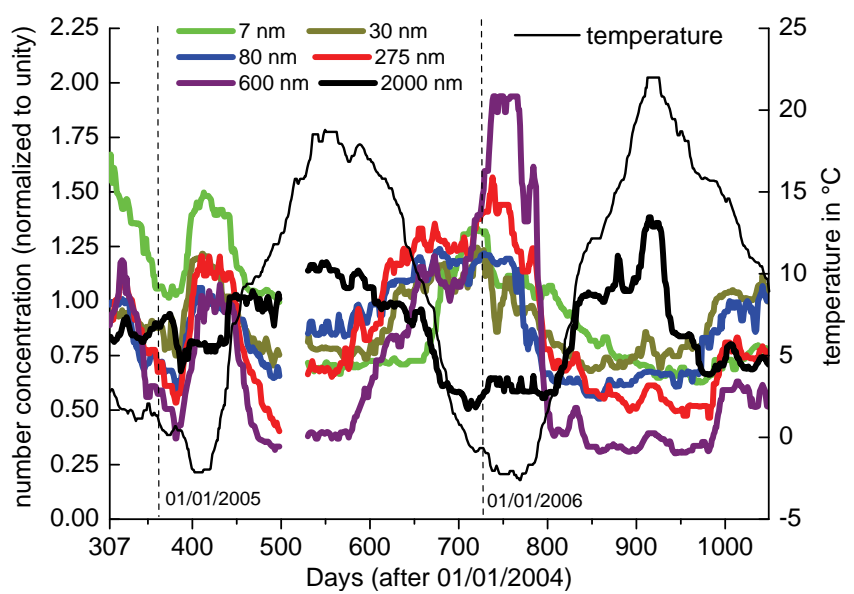

Fig. 4. Time series of particle number concentration (30-day running median values) over the entire two-year period. Shown are the particle concentrations at discrete particle diameters, each normalised to an average of unity. Time is coded in days after 01 January 2004. The thin line indicates ambient temperature (30-day running median).

lower scale of worldwide urban background observations (5000-50000 $\mathrm{cm}^{-3}$ ). We particularly took note of the longterm observations (i.e. covering more than one year) reported for Alkmaar and Erfurt (both $18000 \mathrm{~cm}^{-3}$; Ruuskanen et al., 2001), Helsinki $\left(16000 \mathrm{~cm}^{-3}\right.$; Ruuskanen et al., 2001), Leipzig $\left(16000 \mathrm{~cm}^{-3}\right.$; Wehner and Wiedensohler, 2003), Copenhagen (7000 and $24000 \mathrm{~cm}^{-3}$; Ketzel et al., 2004), Pittsburgh (22000 $\mathrm{cm}^{-3}$; Stanier et al., 2004), Atlanta $\left(21000 \mathrm{~cm}^{-3}\right.$; Woo et al., 2001), and Beijing $\left(33000 \mathrm{~cm}^{-3}\right.$; Wehner et al., 2008).

\subsubsection{Annual cycle}

Annual cycles of environmental parameters are helpful to identify possible seasonal changes, such as related to temperature, humidity, and also the activity of natural and anthropgenic particle sources. Figure 4 presents particle number concentrations for six discrete particle diameters $(7,30$, $80,275,600$, and $2000 \mathrm{~nm}$ ). Similarly to Sect. 3.1.1 the diameters were selected so that statistically independent particle populations are represented. In addition, the time series were normalized to an average of unity, and smoothed by a running 30-day median.

Figure 4 highlights the occurrence of high number concentrations during enduring periods with cold ambient temperatures. A closer look at the time series - shown in detail in Fig. 15 in the appendix, revealed that the high particle concentrations were associated with several cold periods, where temperatures fell particularly low. These were, in detail, 16-19 January, 2005 (day 381-384): minimum temperature $-7.8^{\circ} \mathrm{C} ; 28-31$ January 2005 (day $\left.393-396\right):-12.2^{\circ} \mathrm{C}$; 5-9 February 2005 (day $401-405$ ): $-11.7^{\circ} \mathrm{C} ; 22-28$ February 2005 (day $418-424$ ): $-11.9^{\circ} \mathrm{C}$; 3-5 March 2005 (day 
Table 1. Particle number concentrations in Augsburg for specific particle size intervals. $\mu$ indicates the arithmetic mean, $\sigma$ the standard deviation, $\sigma_{\mu}$ the standard deviation of the mean, and $p_{k}$ the $k$ th percentile of the concentration in the corresponding size interval.

\begin{tabular}{lrrrrrrrrrr}
\hline$D_{p}$ range & $\mu$ & $\sigma_{\mu}$ & $\sigma$ & $p_{1}$ & $p_{5}$ & $p_{25}$ & $p_{50}$ & $p_{75}$ & $p_{95}$ & $p_{99}$ \\
\hline $3-10 \mathrm{~nm}$ & 790 & 19 & 1300 & 74 & 140 & 310 & 530 & 870 & 1900 & 6300 \\
$10-30 \mathrm{~nm}$ & 3700 & 46 & 3000 & 530 & 850 & 1700 & 2900 & 4700 & 9300 & 15000 \\
$30-300 \mathrm{~nm}$ & 7600 & 96 & 6300 & 1300 & 2100 & 3800 & 5900 & 9400 & 19000 & 30000 \\
$300-800 \mathrm{~nm}$ & 150 & 3 & 170 & 930 & 17 & 4700 & 100 & 200 & 430 & 850 \\
$800-2000 \mathrm{~nm}$ & 2 & 0.04 & 3 & 0.12 & 0.27 & 0.65 & 1 & 2 & 7 & 1500 \\
$2000-10000 \mathrm{~nm}$ & 0.16 & 0.01 & 0.13 & 0.01 & 0.03 & 0.07 & 0.12 & 0.20 & 0.39 & 0.65 \\
\hline
\end{tabular}

427-429): $-12.5^{\circ} \mathrm{C}$; 10-16 January 2006 (day 740-746): $-10.4^{\circ} \mathrm{C}$; 23 January-2 February 2006 (day 753-765): $-12.4^{\circ} \mathrm{C}$. It is mainly these episodes which lead to a substantial difference in average total particle number between winter (December-February; $15000 \mathrm{~cm}^{-3}$ ) and summer (June, July, August; $10000 \mathrm{~cm}^{-3}$ ).

The enhanced concentrations in winter are attributed to two effects: additional particulate emissions from domestic heating and power generation and second, less pronounced vertical mixing of the atmosphere. Both effects are particularly the consequence of very cold temperatures. Such an annual cycle is not unusual but has been observed in other urban size distribution data sets in the Northern Hemisphere before (Wichmann et al., 2002; Wehner and Wiedensohler, 2003; Hussein et al., 2004; Aalto et al., 2005).

We observed that the concentrations of $7 \mathrm{~nm}$ particles showed a similar annual cycle as the rest of the sub- $\mu$ m particles. Atmospheric particle formation events as a result of photochemical processes were only rarely observed in Augsburg, even during the warm season. Thus, the new particle formation events have no significance for the annual cycle in Fig. 4.

In much contrast to the $7 \mathrm{~nm}$ particles, coarse particles at $2000 \mathrm{~nm}$ show a concentration maximum in summer, with concentration being higher by approximately $50 \%$ compared to winter. In Fig. 4 there is a positive correlation between coarse particle concentrations and temperature $\left(R^{2}=0.5\right)$. These observations suggest an increased probability of particle re-suspension from agricultural lands and roads under the rather dry conditions in summer.

\subsubsection{Diurnal cycle}

Figure 5 gives diurnal cycles of the particle number concentrations at the six previously selected diameters. The data are distinguished between weekdays (Monday-Thursday), Saturdays and Sundays. At all particle diameters the concentrations reveal a maximum during the morning peak traffic period (06:00-09:00 LT). Its occurrence in all particle diameters suggests a broad impact of traffic emissions on the entire particle size spectrum. The relative magnitude of this morning peak is the greatest for the lowest particle diameters 7, 30 and $80 \mathrm{~nm}$. While the latter particle diameters are in particular indicative of exhaust emissions, coarse particles - represented by the $2000 \mathrm{~nm}$ diameter in Fig. 5f, have rather been associated with direct sources due to abrasion and vehicleinduced re-suspension (Thorpe and Harrison, 2008).

The particle concentrations at all diameters decreased steadily as of 08:00 towards noon. This re-occurring feature is ascribed to the dilution of the emitted pollutants in an increasingly well-mixed boundary layer rather than changes in traffic density, the latter remaining rather constant throughout the daylight hours. The morning peak turns out considerably lower on Saturdays, and is entirely missing on Sundays as a result of lower traffic densities at that time of day.

For the particle diameters 30, 80, 275 and $600 \mathrm{~nm}$, concentrations show a second maximum in the evening (20:0024:00 LT) as well. We suspect that this second maximum is the result of pollution trapping, since it coincides with the time of re-stratification in the urban atmosphere rather than any increase in traffic. The observations highlight the relevance of urban traffic emissions on the HMGU station in Augsburg, but similar to comparable observations at urban background locations in German cities of comparable size (Wehner and Wiedensohler, 2003; Cyrys et al., 2003).

\subsubsection{Auto-correlation analysis}

Figure 6 shows the auto-correlation function (ACF) for five selected size channels $(10,50,120,600$, and $5000 \mathrm{~nm})$. The ACF of 10 and $50 \mathrm{~nm}$ particles decreases rapidly with lag time, indicating a low persistence of their concentrations in the urban atmosphere. However, their concentrations exhibit a significant diurnal autocorrelation, manifested by local maxima in the ACF at multiples of $1 \mathrm{~d}$. When passing over to larger particles, the diurnal autocorrelation becomes less significant, at the benefit of a slower decrease of the ACF with the lag time, indicating a higher persistence of the concentrations. The diurnal autocorrelation reappears as a sinusoidal signal in the coarse particle mode $(5000 \mathrm{~nm})$, indicating the activity of coarse particle sources on a diurnal scale.

The time variations were analysed more systematically by splitting the ACF into different components by a least-square fit. Four component functions were fitted: $F_{A}$, a decreasing 

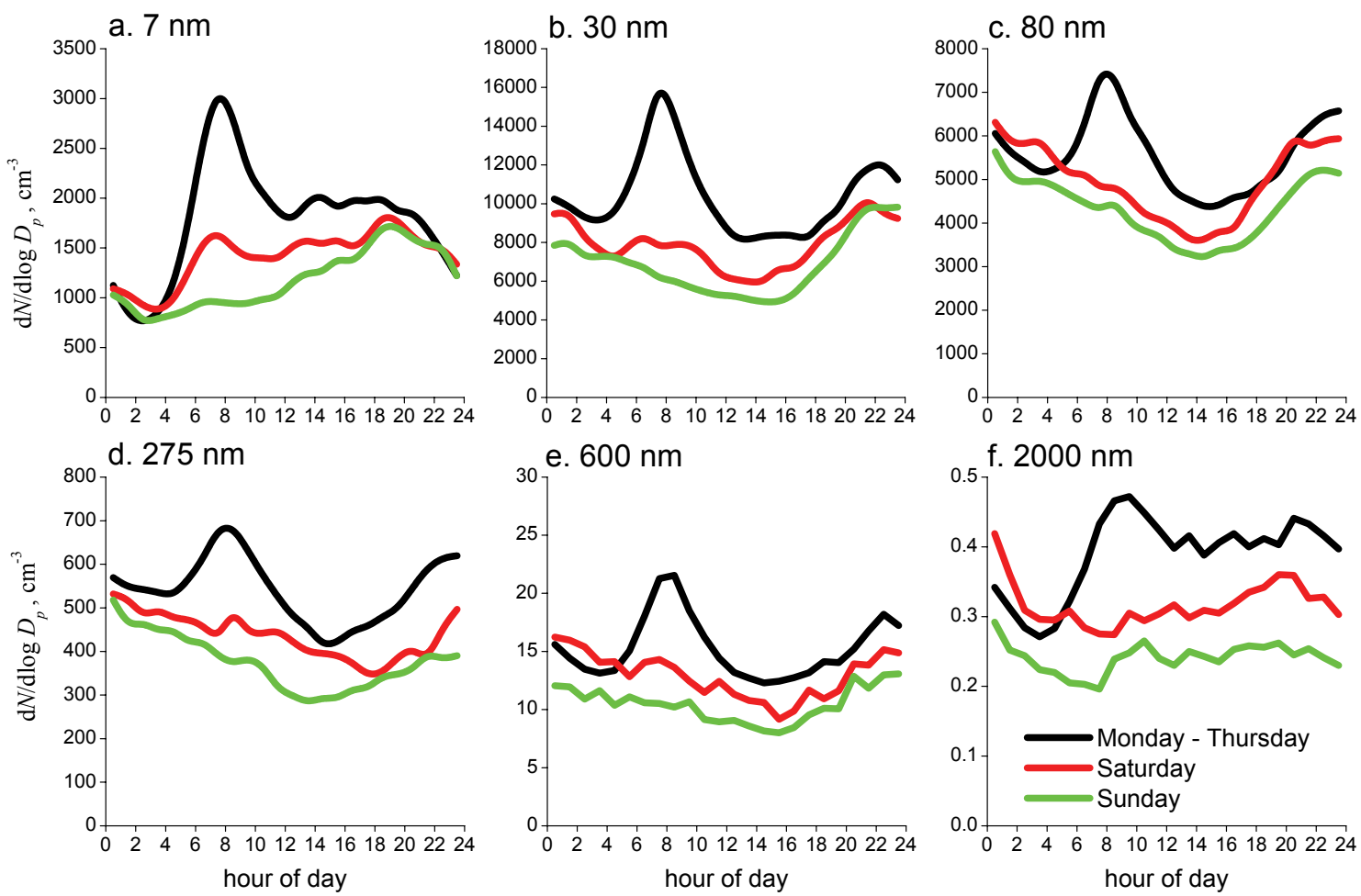

Fig. 5. Average diurnal cycle of particle number concentration at (a) $7 \mathrm{~nm}$, (b) $30 \mathrm{~nm}$, (c) $80 \mathrm{~nm}$, (d) $275 \mathrm{~nm}$, (e) $600 \mathrm{~nm}$ and (f) $2000 \mathrm{~nm}$. The data cover the entire measurement campaign and are keyed after different periods of the week.

exponential curve representing the persistent (long-lasting) component; $F_{B}$, a sinusoidal curve with period time $1 \mathrm{~d}$ representing the daily periodical component; $F_{C}$, a sinusoidal curve with period time $7 \mathrm{~d}$ representing the weekly periodical component; $F_{D}$, an additional constant used for achieving a better numerical fit. Figure 7 shows the integrals values over $F_{A}, F_{B}$, and $F_{C}$ as a function of particle size.

As indicated in Fig. 6 before, the persistent component $F_{A}$ was found to be dominant between 100 and $5000 \mathrm{~nm}$, peaking at $600 \mathrm{~nm}$. This confirms the accumulation mode and the lower part of the coarse particle mode as the long-lasting aerosol components at the HMGU station in Augsburg: The concentrations in the size range $100-5000 \mathrm{~nm}$ change only slowly; they are determined by atmospheric processes lasting a few days and longer.

The diurnal component $F_{B}$, in contrast, was dominant in the size range $<10 \mathrm{~nm}$ and showed non-negligible contributions $>2000 \mathrm{~nm}$. In the size range $<10 \mathrm{~nm}$, this points to daily variations of newly formed particles as a result of photochemical processes along with solar radiation, while in the coarse mode it indicates the activity of abrasion and resuspension sources. Finally, the weekly periodic component $F_{C}$ shows a maximum at $20 \mathrm{~nm}$ and a minor maximum in the coarse mode. The weekly component reflects, in any case, co-variations over 7 days and therefore represents the intensity of anthropogenic contributions.

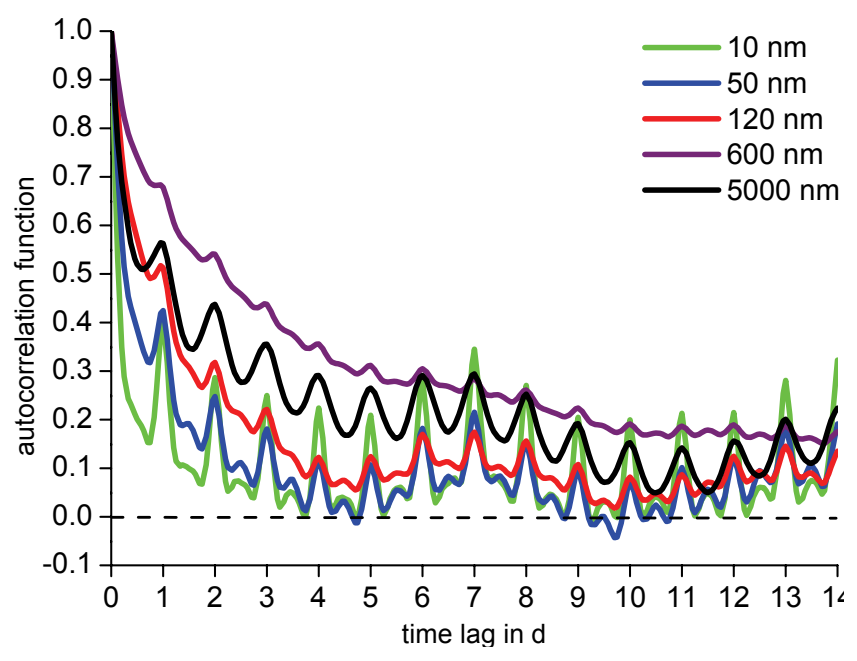

Fig. 6. Auto-correlation function of particle number concentration at selected particle diameters.

Based on Figs. 5 and 7 we draw the following conclusions: Particles observed at the HGMU station in Augsburg in the size range $10-30 \mathrm{~nm}$ seem to derive at high proportions from vehicle exhaust. This derives from their sensitivity on the day of the week, Fig. $5 \mathrm{~b}$ being representative of $30 \mathrm{~nm}$ particles, and the prevalence of the weekly, necessarily anthropogenic component in the ACF (Fig. 7). Particles smaller than $10 \mathrm{~nm}$ 
still originate from traffic in notable amounts (cf. morning maximum in Fig. 5a); however, an increasing influence on photochemical secondary formation can be noticed with decreasing diameter. A crucial indication, on the one hand, is the relative increase of the mid-day levels of $7 \mathrm{~nm}$ particles (10:00-18:00 LT - partially attributed to photochemical particle production) compared to those of $30 \mathrm{~nm}$ and $80 \mathrm{~nm}$ particles (Fig. 5a). On the other hand, the weekly periodical component $F_{C}$ in the ACP diminishes below $10 \mathrm{~nm}$ and falls short of the daily periodical component $F_{B}$. We are aware, however, that the methods used here do not permit a highly quantitative assessment of the relative contributions of the different sources to the observed particle concentrations.

Moving beyond the size range of particles $<30 \mathrm{~nm}$, particle concentrations in the range $30-300 \mathrm{~nm}$ exhibit a significant influence of regional particulate emissions, while particles between 300 and $800 \mathrm{~nm}$, that show the least periodical variations (Fig. 7), represent the long-range transported fraction of the aerosol. (The latter conclusion is not new, but has been previously obtained for the Central European troposphere, for instance, by air mass analysis of particle size distributions, Birmili et al., 2001, or statistical multiple-site analysis, Costabile et al., 2009). Due to their increasing diurnal variability (Figs. 6 and 7), particles in the intervals $0.8-$ $2.0 \mu \mathrm{m}$ and $2-10 \mu \mathrm{m}$ are again assumed to originate regional and local sources, such as direct vehicle emissions, vehicleinduced re-suspension, but also wind-blown dust.

\subsection{Particle data after volatilisation at $300{ }^{\circ} \mathrm{C}$}

\subsubsection{Number concentrations and size distributions}

Passage through the thermodenuder (TD) modifies the particle size distribution, notably shifting the size distribution to smaller diameters (Fig. 3). An essential result was that that the total particle number remained virtually unchanged after passage through the thermodenuder (Fig. 2), i.e. it seems that within the accuracy of the measurement, every particle has a core that is non-volatile at $300^{\circ} \mathrm{C}$. As expected, the effect of thermal conditioning on the total particle volume was rather significant: on average, $69 \%$ of the particulate volume concentration $\left(D_{p}<800 \mathrm{~nm}\right)$ was removed by the TD, leaving a non-volatile volume fraction of $31 \%$.

In contrast to the monomodal size distribution of nonconditioned particles, the distribution of non-volatile residuals exhibited two peaks around 10 and $70 \mathrm{~nm}$, respectively (Fig. 3). We explain this transformation of a broad monomodal into a bimodal distribution by the presence of an external particle mixture: first, a sub-population of nearly non-volatile particles exists, which remains at roughly their original size. Second, a population of partly volatile particles exist, which shrink to a small fraction of their original size. Earlier volatility analyser measurements in Leipzig suggested that these two populations are relatively well separated, i.e. very few particles show a transitional behaviour be-

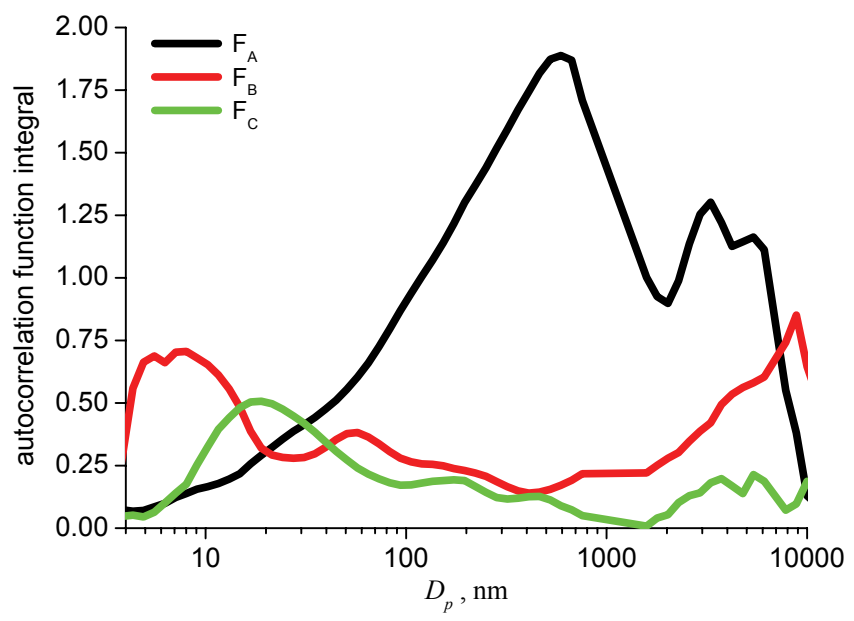

Fig. 7. Integrals of the three auto-correlation function components $(0<t<14 \mathrm{~d})$ as a function of particle diameter $D_{p}$. Here, $F_{A}$ is the persistent (long-lasting) component, $F_{B}$ the daily periodical component and $F_{C}$ the weekly periodical component.

tween these two particle types (Rose et al., 2006). The latter authors also suggested the non-volatile mode around $70 \mathrm{~nm}$ to represent direct vehicular soot emissions, which is plausible in view of the characteristics of soot particles detected in diesel exhaust (Sakurai et al., 2003; Ntziachristos et al., 2004; Kittelson et al., 2006). One might argue that crustal material (e.g. silicates) originating from re-suspension might interfere with the primary soot particles in the thermodenuder measurements. An electron microscopic study in the urban atmosphere of Frankfurt (Germany), however, rejected that argument by identifying the overwhelming majority of urban particles around $100 \mathrm{~nm}$ as soot, and not crustal material (Vester et al., 2007).

In contrast to the diesel soot mode, there is much less knowledge about the nature of particles the non-volatile mode around $10 \mathrm{~nm}$ observed in Augsburg (Fig. 3). While it seems evident that they are the residuals of bigger, partly volatile particles, the chemical composition of their residuals is unknown. Both Wehner et al. (2005) and Ehn et al. (2007) found that even particles $<20 \mathrm{~nm}$ originating from photochemically-induced nucleation, i.e. particles that were at maximum a few hours old, contained a core that was nonvolatile at $300^{\circ} \mathrm{C}$. In view of these results it appears necessary to assume that relatively rapid chemical conversions take place within the particle phase, thereby generating thermally resistant compounds. The photooxidation of aromatic compounds in a reaction chamber gave evidence for the generation of thermally resistant polymers (Kalberer et al., 2004) but it remains unclear to what extent the described processes are relevant to the real urban atmosphere. 


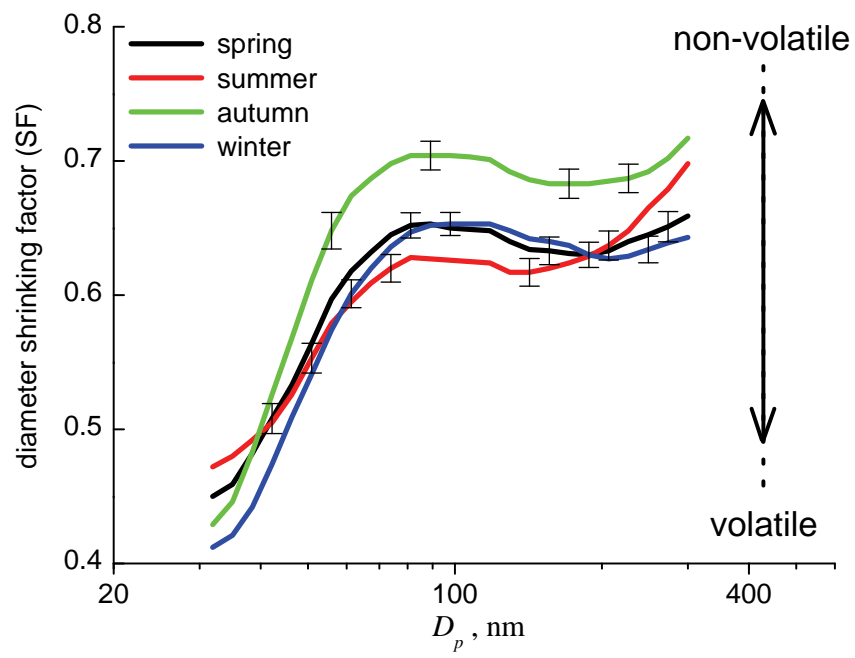

Fig. 8. Particle diameter shrinking factor (SF) due to thermodesorption at $300^{\circ} \mathrm{C}$. The data cover the morning traffic peak hours (06:00-09:00 CET) and are keyed after season. Whiskers represent plus/minus one sigma of the mean.

\subsubsection{Size-dependent shrinking factors}

The shrinking factor (SF) indicates the diameter fraction onto which the average particle population of a given size collapses after passing through the TD. Figure 8 shows SF as a function of particle diameter for the morning peak hours (06:00-09:00), i.e. when the contribution of fresh anthropogenic aerosol was the highest.

The SF values rise continuously from 30 to about $100 \mathrm{~nm}$. Low values between 0.4 and 0.5 at $30 \mathrm{~nm}$, indicate relatively low volume fractions of non-volatile material (ca. 10\%). Conversely, this indicates higher volume fractions of volatile species (ca. 90\%), among which we presume organic compounds from direct vehicle exhaust emissions but also secondary processes. Between 70 and $120 \mathrm{~nm}$, a relative maximum in SF and thus the non-volatile fraction is reached (Fig. 8). This maximum coincides with the size range of diesel emissions as discussed before. An intermediate minimum around $200 \mathrm{~nm}$ indicates an increasing trend in the volatile fraction while the non-volatile fraction grows slowly again towards $300 \mathrm{~nm}$.

Although the size-segregated trends above $100 \mathrm{~nm}$ are on the borderline of significance, they might plausibly be explained by liquid phase-production of soluble material during the processing of particles in non-precipitating cloud, which is most relevant just above the activation size of cloud condensation nuclei $(\sim 100 \mathrm{~nm})$. The second, slightly increasing trend towards $300 \mathrm{~nm}$ would be consistent with a growing importance of crustal material with increasing particle size reported in Vester et al. (2007).

When differentiating the data after season, the maximum of non-volatile material ( $\mathrm{SF} \sim 0.7)$ was observed during autumn (September-November). A likely explanation was that

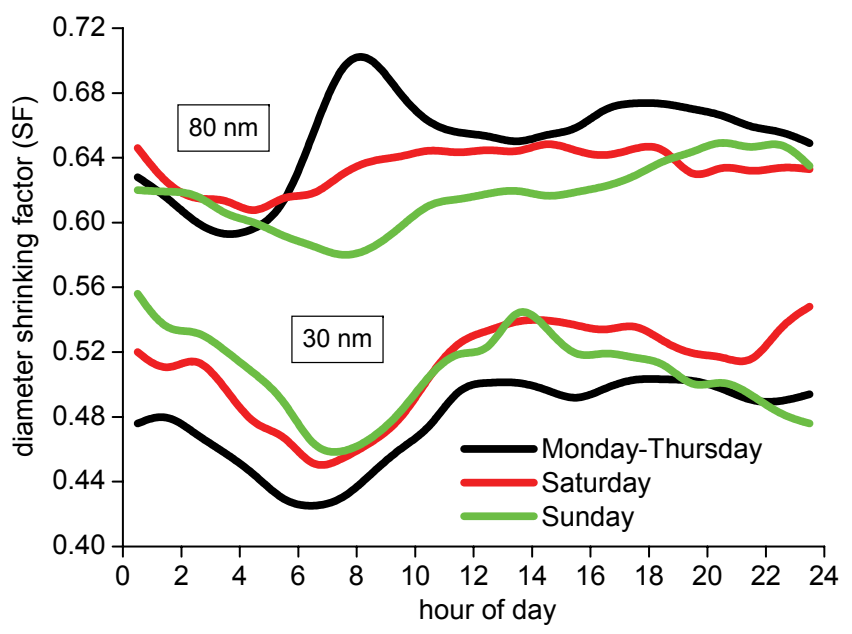

Fig. 9. Average diurnal cycle of the diameter shrinking factor (SF) of $30 \mathrm{~nm}$ and $80 \mathrm{~nm}$ particles. The data are also distinguished between weekdays and weekends.

during our measurements, the absolute number concentrations during the morning peak hours (06:00-09:00) were the highest during the autumn period: The autumn number concentrations at $80 \mathrm{~nm}$ were, for instance, $10 \%$ higher than during winter (December-February), 25\% higher than in summer (June-August), and 28\% higher than in spring (MarchMay). The concentrations measured during the the morning peak hours are expected to be the most strongly influenced by traffic sources, thereby contributing non-volatile diesel soot particles.

The $24 \mathrm{~h}$-average SFs of particles between 30 and $300 \mathrm{~nm}$ ranged between 0.45 and 0.70 in Augsburg while observations at a rural site in East Germany (Melpitz) yielded average values between 0.35 and 0.55 (Engler et al., 2007). The corresponding non-volatile volume fractions are $0.09-0.34$ in Augsburg and 0.04-0.17 in Melpitz. Thus, non-volatile particle material is enriched in urban background PM in Augsburg by a factor of two compared to the rural background atmosphere of Melpitz. This observation is of relevance for the assessment of particle exposure caused by non-volatile particulate carbon.

\subsubsection{Diurnal cycles of SF}

Figure 9 shows the diurnal cycles of SF for the particle sizes 80 and $30 \mathrm{~nm}$. These populations are remarkable with respect to their relatively high and low fractions of non-volatile particle material (Fig. 8). The diurnal cycle of SF $\left(D_{p}=80 \mathrm{~nm}\right)$ exhibits a pronounced morning maximum at 08:00, in close analogy to the particle number concentration upstream of the TD (Fig. 6). This reflects, again, enhanced traffic emissions as well as a stratified boundary layer in the morning hours. The corresponding non-volatile volume fractions at 08:00 are 0.37 on weekdays, and 0.19 on Sundays. Combining this information with the rough doubling of particle concentrations 
from Sundays to weekdays at the mass-dominating particle diameters 275 and $600 \mathrm{~nm}$ (Fig. 5d-e) leads to the conclusion that up to $50 \%$ of the non-volatile particle volume in the urban background of Augsburg can stem from traffic within the city itself.

For SF $\left(D_{p}=30 \mathrm{~nm}\right)$ the case is rather different (Fig. 9). Here, the morning peak was missing on weekdays as well as on weekends. Instead, SF shows a consistent minimum during the morning rush hour period (06:00-09:00). Moreover, SF tends to show lower overall values on weekdays compared to weekends. Two conclusions can be drawn here: First, urban $30 \mathrm{~nm}$ particles contain considerably less non-volatile material than $80 \mathrm{~nm}$ particles, as found already above. Second, traffic-derived $30 \mathrm{~nm}$ particles contain a disproportionately smaller fraction of non-volatile material, as opposed to $80 \mathrm{~nm}$ particles. The latter conclusion is consistent with the observed high volatility of traffic-derived condensation particles (Sakurai et al., 2003). The observations in Fig. 9 highlight the possibility of the TDMPS/TD method to quantify the influence of traffic-derived particles on the mixture of particle types at an urban background site.

\subsubsection{Non-volatile particle volume vs. black carbon concentration}

In Augsburg, gravimetric $\mathrm{PM}_{2.5}$ and $\mathrm{PM}_{10}$ mass concentrations were observed to highly correlate with the mass concentrations calculated from the TDMPS/APS number size distributions (Pitz et al., 2008b). Here, however, we scrutinised another correlation: the non-volatile volume concentration $\left(D_{p}<800 \mathrm{~nm}\right)$ versus the black carbon (BC) mass concentration in $\mathrm{PM}_{2.5}$ using the aethalometer. The aethalometer data include the corrections against the MAAP described above. It is also worth mentioning that the upper size cutoffs of both methods are different. The size range $<800 \mathrm{~nm}$, however, encompasses the majority of the $\mathrm{PM}_{2.5}$ mass concentration (90\% based on Fig. 3), so the influence of different upper cut-off sizes are presumed to play a subordinate role.

A scatter plot between the $\mathrm{BC}$ mass concentration and the non-volatile particle volume can be seen in Fig. 10. Linear curves were fitted for each season, with coefficients of determination $\left(R^{2}\right)$ of $0.88,0.93,0.82$ and 0.87 for winter (December-February), autumn (September-November), summer (June-August) and spring (March-May), respectively. Given that black carbon makes up only a sub-fraction of the total PM, the high degree of correlation indicates a close association between the non-volatile and the lightabsorbing components of PM in Augsburg. It is worthy to note that the fit curves shows a positive intercept on the axis of $\mathrm{BC}$; the reason for this intercept is currently unclear.

Based on Fig. 10, one unit amount of non-volatile PM appears to cause more light absorbance in winter compared to summer. The reasons could be differences in the mixing state of the non-volatile PM, and also incorrect assumptions on the sphericity of the particles. Both arguments are likely to be

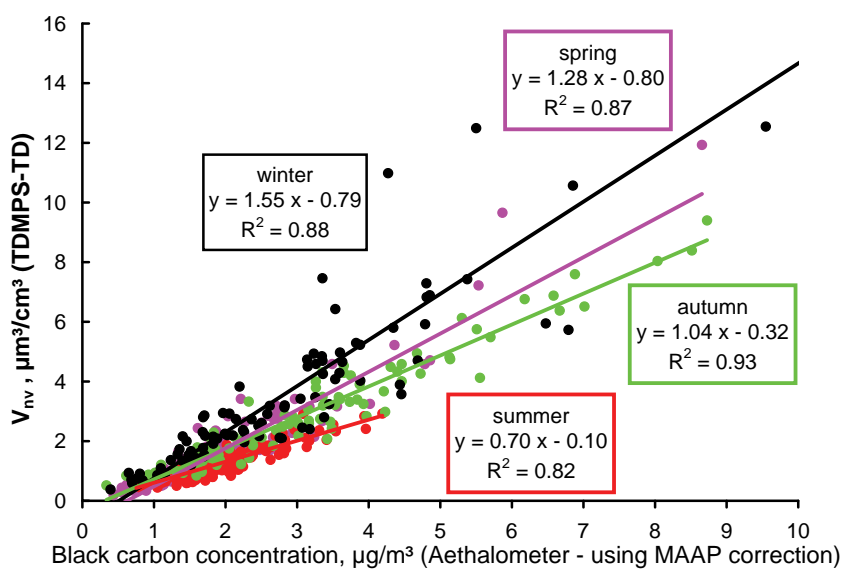

Fig. 10. Black carbon mass concentration (aethalometer) versus the non-volatile particle mass concentration $\left(D_{p}<800 \mathrm{~nm}\right.$; TDMPSTD) on the basis of daily averages.

related to the enhanced contributions of soot from domestic heating, power generation, and also traffic in winter.

Another explanation, which is hard to verify, could be the presence of absorbing aerosol other than soot during the summer period. Soil dust particles in the aerodynamic size range $1-2.5 \mu \mathrm{m}$ can easily contain light absorbing material that the aethalometer reports as BC. Nevertheless, the comparison between both methods suggests that the non-volatile particle volume can serve as a surrogate for the mass concentration of black carbon and vice versa.

\subsection{Effects of the mixed layer height}

The mixed layer height (MLH) is the most important single meteorological parameter describing the likelihood of vertical air exchange and pollutant dispersal. Low MLHs inhibit the dispersal of the pollutants emitted near the ground, particularly under low wind speeds. Here, we sought for a possible connection between the concentrations of non-volatile particles and the MLH.

Figure 11 shows the relationship between the non-volatile particle volume concentration and the MLH based on the 13:00 radiosoundings. A well-known feature is the prevalence of high MLHs in the summer period; half of the values exceeded $1400 \mathrm{~m}$. A significant anti-correlation can be seen between the particle volume and the MLH. In fact, the highest non-volatile volume concentrations (range 6$20 \mu \mathrm{m}^{3} \mathrm{~cm}^{-3}$ ) were only observed for MLHs below $500 \mathrm{~m}$, while concentrations $>3 \mu \mathrm{m}^{3} \mathrm{~cm}^{-3}$ occurred only for MLHs below $1200 \mathrm{~m}$. Meanwhile, high MLHs above $1300 \mathrm{~m}$ led to concentrations mainly below $2 \mu \mathrm{m}^{3} \mathrm{~cm}^{-3}$.

It is essential to note that Fig. 11 describes aerosol effects in Augsburg, which are associated with a MLH that is representative for a large area, perhaps a few $100 \mathrm{~km}$ but in any case smaller than the synoptic weather scale. We acknowledge that the lack of profiling measurements directly in the 


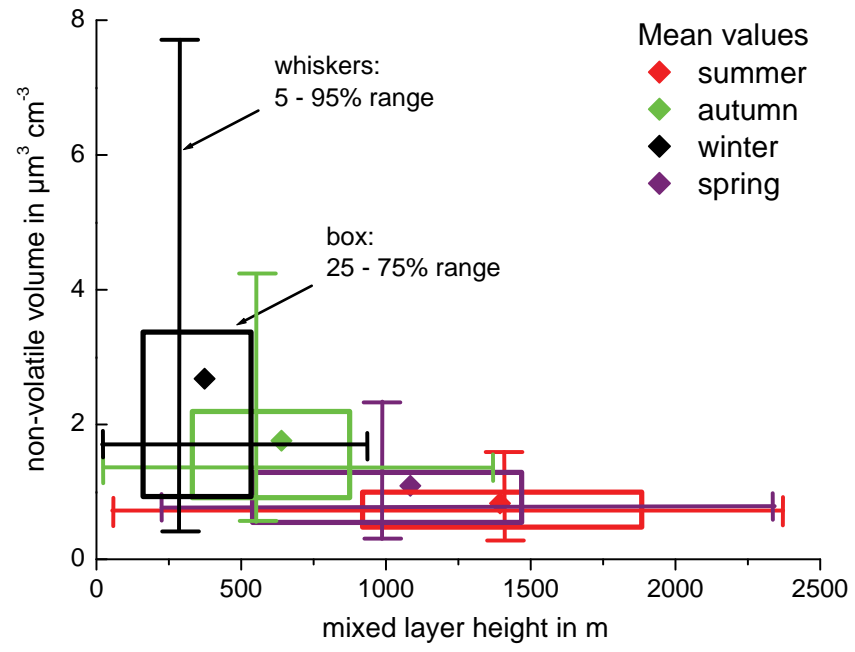

Fig. 11. Relationship between the mixed layer height and the nonvolatile particle volume concentration $\left(D_{p}<800 \mathrm{~nm}\right)$. The Figure indicates mean values as well as $25-75 \%$ and $5-95 \%$ percentile ranges (box, and whiskers, respectively).

city Augsburg might be a constraint of the comparison shown in the figure. Nevertheless, we find our results very consistent with the formerly observed dependency of $\mathrm{PM}_{10}$ on the MLH in various European cities (Kukkonen et al., 2005; Schäfer et al., 2006).

From a public health point of view, it is suggestive that these episodic values of non-volatile particulate volume concentration $>3 \mu \mathrm{m}^{3} \mathrm{~cm}^{-3}$ (which are associated with black carbon) would be associated with a higher health risk due to the inhalation of ambient aerosols. It is worthy to note that a low MLH does not necessarily imply low particulate volume concentrations: For MLHs $<500 \mathrm{~m}$, the majority of particle volume concentrations is below $2 \mu \mathrm{m}^{3} \mathrm{~cm}^{-3}$. Other factors, such as the geographic origin of the air mass play a confounding role in determining the local particle concentrations.

\subsection{Effects of wind direction and air masses}

Local wind speed and wind direction can be essential factors in determining particle concentrations in urban areas. For Augsburg, the particle number concentration is shown as a function of the local direction in Fig. 12. Here, we employed the wind direction measured at the FH Augsburg roof-top site (cf. Sect. 2.2), which is assumed to be representative of a wide area of the city. Figure 12 suggests a moderate but systematic dependency: Concentrations are systematically lower under westerly winds at all particle diameters compared to easterly winds. Importantly, the lowest concentrations at wind direction $\sim 240^{\circ}$ coincide with the statistically highest wind speed, which facilitates pollution dispersal. The particle diameters 275 and $600 \mathrm{~nm}$ - representative of longrange transported aerosols, show pronounced maxima from

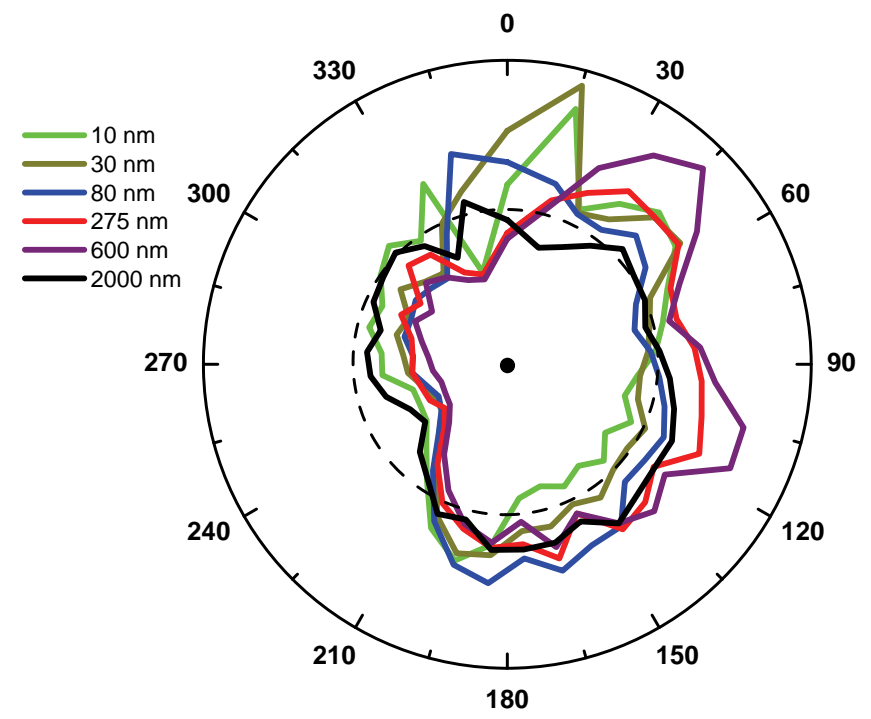

Fig. 12. Wind-directional dependence of particle number concentration in Augsburg. Shown is the median concentration for different intervals of wind direction. For a better comparability, the number concentration in each size channel was normalised to unity.

easterly, i.e. continental directions. The particle diameters 10,30 , and 80 , influenced by traffic sources, show a maximum from northerly direction, coinciding with the location of several major roads and the city centre (cf. Fig. 1). These wind-directional characteristics were explored further using back trajectory analysis in the following.

Figure 13 shows the 13 mean back trajectories obtained from k-means cluster analysis. Figure $14 \mathrm{a}-\mathrm{c}$ gives the mean particle size distributions (total and non-volatile), and mean virtual potential temperature profiles obtained from radiosoundings at 13:00 LT. Table 2 describes the mean characteristics of the 13 back trajectories obtained by the cluster algorithm. The air masses arriving in Augsburg can be classified as either maritime-influenced (wind direction west) or continentally influenced (wind direction east). The particle number distributions in Fig. 14a show generally a single maximum between 20 and $50 \mathrm{~nm}$. Due to their small size, these particles are interpreted as being formed over the continent, eventually within an area encompassing southern Germany. Particles bigger than $100 \mathrm{~nm}$, particularly those between 300 and $1000 \mathrm{~nm}$ are, in contrast, influenced by larger scale processes, as was evident from the maximum in the persistent auto-correlation component (Fig. 7).

A major observation was that the lowest particle number concentrations in Augsburg were associated with maritime air masses (Cluster Nos. 1, 2, 3, 13). This is consistent with earlier studies at tropospheric background locations (Birmili et al., 2001; Tunved et al., 2003). Surprisingly low number concentrations were observed for two continental clusters (Nos. 6 and 7). A likely reason for these low concentrations is the unusually low vertical stability (Fig. 14c) during 


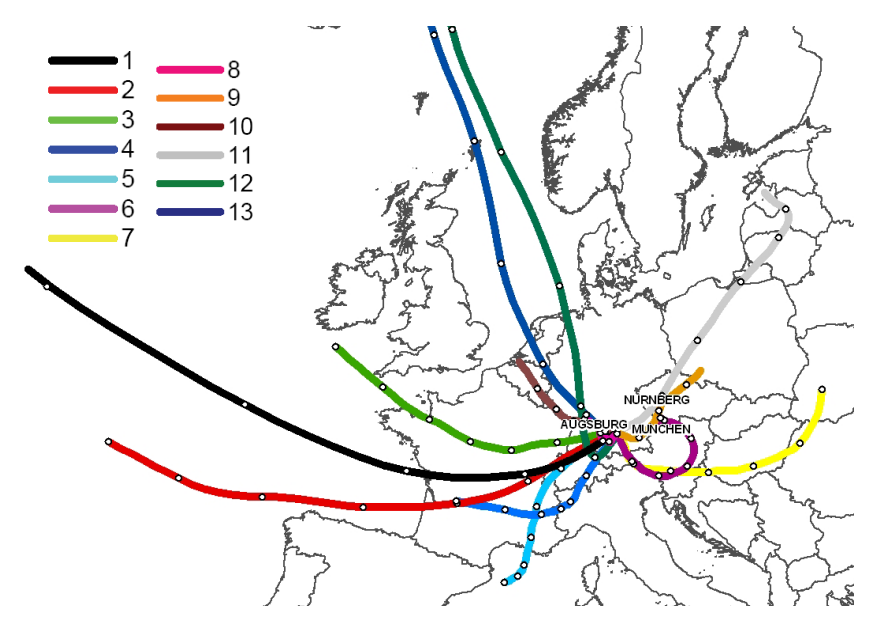

Fig. 13. Mean back trajectories of 13 trajectory clusters arriving at Augsburg. The duration of each trajectory is 6 days. One trajectory point corresponds to $24 \mathrm{~h}$. Trajectory No. 8 , corresponding to stagnant air masses, is so short that it is not discernable in the figure.

summer time conditions (Table 2, season index). The trajectory clusters featuring the highest particle number concentrations were Nos. 12, 4 and 8. These clusters are representative of subsiding air from the North Atlantic (No. 12), slow south-westerly air subsiding from the Alps (Nos. 4) and stagnant air over Southern Germany (No. 8). These air masses originate from entirely different large-scale directions. Conversely, trajectory clusters representing continental air masses from Eastern Europe do not belong to those clusters with the highest particle numbers (Nos. 7, 8, $9,11)$. The likely reason for the high concentrations associated with the clusters Nos. 12, 4 and 8 is the extraordinary atmospheric stability, with virtual potential temperature gradients between 0.005 and $0.01 \mathrm{~K} \mathrm{~m}^{-1}$ in the lowest $500 \mathrm{~m}$ of the atmosphere (Fig. 14c). This vertical stability is assumed to lead to the trapping of regional and urban pollution.

As the main conclusion, the particle size distribution in the urban area of Augsburg is shaped by a combination of rather different effects. The vertical stability of the atmosphere, particularly, proved to be a factor more influential that the local or large-scale wind direction. This is worth considering when using such particle data in future epidemiological studies or particle exposure assessments.

\section{Conclusions}

A comprehensive data set of particle size distributions $(0.003-10 \mu \mathrm{m})$ was collected between 2004 and 2006 in urban air in Augsburg, Germany. The annual cycle of particle number concentration showed higher total particle number concentrations in winter $\left(15000 \mathrm{~cm}^{-3}\right)$ compared to summer $\left(10000 \mathrm{~cm}^{-3}\right)$, similar to previous observations in European cities. An exception was the concentration of coarse particles $(>1 \mu \mathrm{m})$ showing a maximum in summer most likely due to

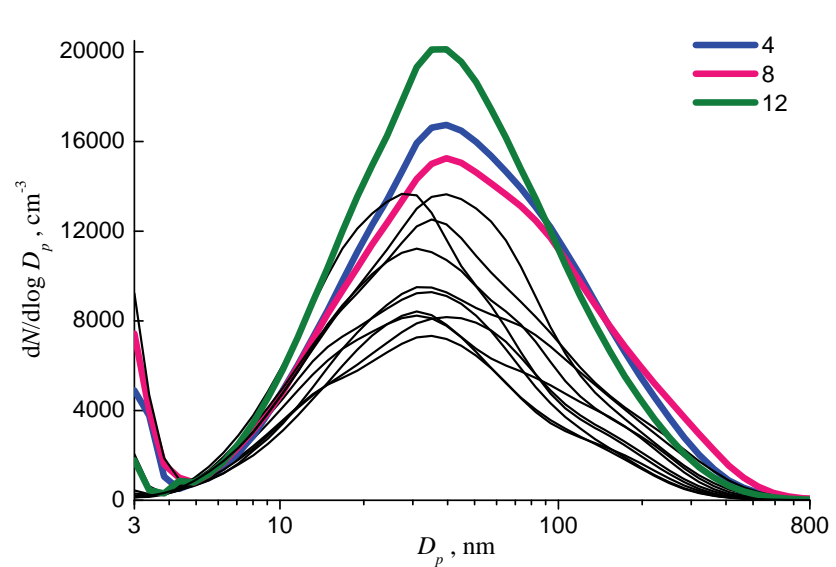

(a)

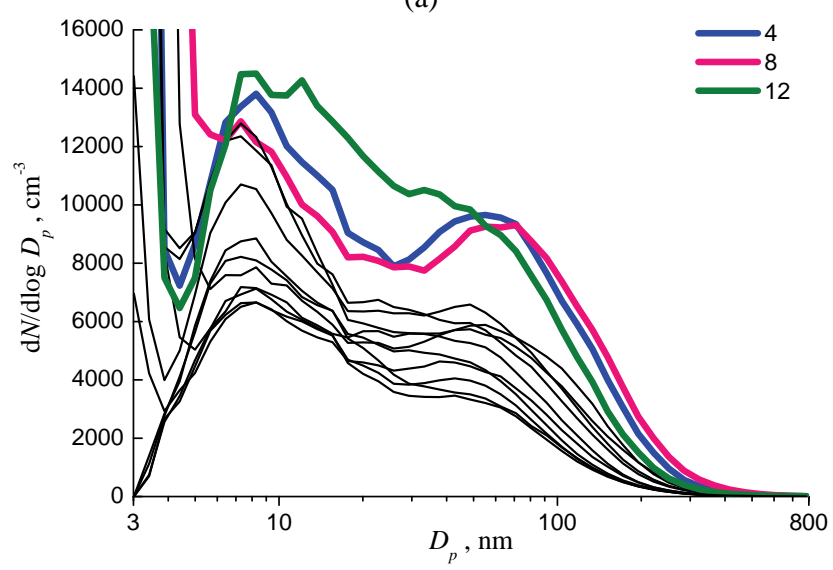

(b)

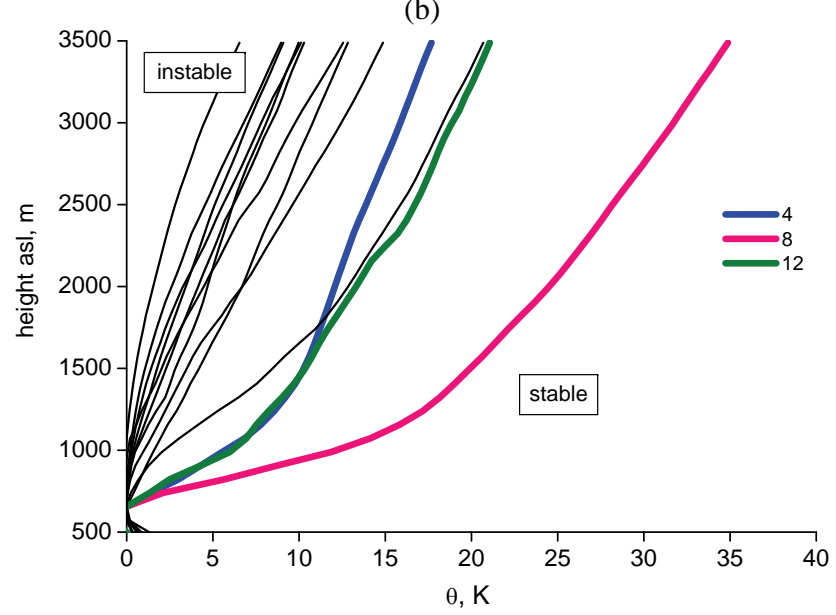

(c)

Fig. 14. Mean characteristics of the 13 back trajectory clusters. The selection highlights the three clusters exhibiting the accumulation mode particle concentrations $(4,8,12)$. All other clusters are only indicated as black lines. For detailed concentrations, see Table 2. (a) Particle number size distributions (12:00-18:00 LT). (b) Non-volatile particle number distributions after volatilisation at $300^{\circ} \mathrm{C}$. High concentrations below $D_{p}=6 \mathrm{~nm}$ result from artificial nucleation inside the thermodenuder. (c) Mean vertical profiles of pseudopotential temperature $(\theta)$ recorded at 13:00 LT. For a direct comparability all profiles were normalised to zero at $h=650 \mathrm{~m}$. 
Table 2. Mean characteristics of the 13 back trajectory clusters. Season index (SI) reflects occurrence in winter $(-1)$ or summer $(+1)$. WD: wind direction, WS: wind speed, MLH: mixed layer height, $N_{[5-800]}$ : total particle number between 5 and $800 \mathrm{~nm}, N_{n v[30-800]}:$ particle number downstream of the thermodenuder $\left(300^{\circ} \mathrm{C}\right)$ between 30 and $800 \mathrm{~nm}$.

\begin{tabular}{|c|c|c|c|c|c|c|c|c|c|c|c|}
\hline \multirow[t]{2}{*}{ No. } & \multirow[t]{2}{*}{ WD } & \multicolumn{2}{|c|}{ Frequency } & \multirow{2}{*}{$\begin{array}{c}N_{[5-800]} \\
\mathrm{cm}^{-3}\end{array}$} & \multirow{2}{*}{$\begin{array}{r}N_{n v[30-800]} \\
\mathrm{cm}^{-3}\end{array}$} & \multirow[t]{2}{*}{ SI } & \multirow{2}{*}{$\begin{array}{r}\text { MLH } \\
\mathrm{m}\end{array}$} & \multirow{2}{*}{$\begin{array}{l}\mathrm{WS}_{\text {traj }} \\
\mathrm{m} \mathrm{s}^{-1}\end{array}$} & \multirow[t]{2}{*}{$\mathrm{WD}_{\text {traj }}$} & \multirow{2}{*}{$\begin{array}{l}\mathrm{WS}_{\text {local }} \\
\mathrm{m} \mathrm{s}^{-1}\end{array}$} & \multirow[t]{2}{*}{$\mathrm{WD}_{\text {loca }}$} \\
\hline & & days & $\%$ & & & & & & & & \\
\hline 1 & W & 28 & 5 & 9100 & 2100 & -0.4 & 1100 & 1.9 & $247^{\circ}$ & 3.8 & $214^{\circ}( \pm 20)$ \\
\hline 2 & SW & 43 & 7 & 8000 & 1900 & -0.1 & 800 & 2.2 & $254^{\circ}$ & 3.5 & $220^{\circ}( \pm 10)$ \\
\hline 3 & NW & 80 & 14 & 7300 & 2200 & 0.2 & 730 & 1.7 & $268^{\circ}$ & 3.2 & $236^{\circ}( \pm 10)$ \\
\hline 4 & SW & 25 & 4 & 17000 & 6400 & -0.4 & 450 & 0.8 & $230^{\circ}$ & 1.5 & $141^{\circ}( \pm 30)$ \\
\hline 5 & $S$ & 78 & 13 & 8000 & 2600 & 0.1 & 540 & 1.3 & $259^{\circ}$ & 2.7 & $207^{\circ}( \pm 20)$ \\
\hline 6 & W & 75 & 13 & 8500 & 3100 & 0.5 & 720 & 0.6 & $0^{\circ}$ & 2.0 & $162^{\circ}( \pm 50)$ \\
\hline 7 & $\mathrm{O}$ & 27 & 5 & 10500 & 3900 & 0.2 & 650 & 0.3 & $121^{\circ}$ & 2.0 & $120^{\circ}( \pm 20)$ \\
\hline 8 & $\mathrm{O}$ & 24 & 4 & 17000 & 6500 & -0.6 & 430 & 0.4 & $152^{\circ}$ & 1.8 & $113^{\circ}( \pm 30)$ \\
\hline 9 & NO & 33 & 6 & 13500 & 3700 & -0.6 & 400 & 0.3 & $75^{\circ}$ & 2.3 & $119^{\circ}( \pm 50)$ \\
\hline 10 & NW & 83 & 14 & 13000 & 3900 & -0.2 & 560 & 0.6 & $291^{\circ}$ & 2.4 & $184^{\circ}( \pm 80)$ \\
\hline 11 & NO & 42 & 7 & 13000 & 3600 & 0.1 & 730 & 0.9 & $45^{\circ}$ & 2.8 & $134^{\circ}( \pm 80)$ \\
\hline 12 & $\mathrm{~N}$ & 13 & 2 & 19000 & 6200 & -0.6 & 760 & 0.8 & $226^{\circ}$ & 1.9 & $173^{\circ}( \pm 30)$ \\
\hline 13 & $\mathrm{~N}$ & 43 & 7 & 10500 & 2600 & 0.1 & 1000 & 0.9 & $288^{\circ}$ & 3.0 & $207^{\circ}( \pm 20)$ \\
\hline
\end{tabular}

enhanced re-suspension. The most extreme particle number concentrations, particularly in the accumulation mode, occurred predominantly during periods of very low temperatures, typically around $-10^{\circ} \mathrm{C}$, and are concluded to result from a combination of emissions from heating sources and atmospheric temperature inversion.

Auto-correlation analysis and diurnal profiles showed that the concentrations of ultrafine particles $(<80 \mathrm{~nm})$ were dominated by their diurnal and weekly-anthropogenic cycle. While the dominance of the diurnal component for particles $<10 \mathrm{~nm}$ points at the importance of photochemicallyinduced new particle formation, the existence of a weekly component in the size range 10 to $600 \mathrm{~nm}$ emphasizes the role of local and regional anthropogenic sources for that size range. A maximum persistence was found for particle concentrations at $600 \mathrm{~nm}$, which are the most representative for long-range transported aerosol. Coarse particles $>2 \mu \mathrm{m}$ were characterised by a mixture of a persistent and a periodic behaviour.

When heating the ambient aerosol to $300^{\circ} \mathrm{C}$ in a thermodenuder (TD), about $69 \%$ of the particulate volume concentration $(<800 \mathrm{~nm})$ vanished, while the particle number $\left(D_{p}>6 \mathrm{~nm}\right)$ remained constant within the measurement accuracy. The summation method was applied to derive diameter shrinking factors (SF) due to the volatilisation step as a function of particle size. Particles between 60 and $200 \mathrm{~nm}$ shrank, on average, to $0.55-0.70$ of their original diameter. Towards smaller particles $(30 \mathrm{~nm})$, the non-volatile fraction decreased, but increased towards bigger particles $(300 \mathrm{~nm})$.

The diurnal cycle of SF showed a relative maximum for $80 \mathrm{~nm}$ during the morning peak traffic hours (08:00) while for $30 \mathrm{~nm}$ a relative minimum occurred. This emphasizes the presence of soot in traffic-derived $80 \mathrm{~nm}$ particles but also its absence in particulate traffic emissions $<30 \mathrm{~nm}$. Correlations between the non-volatile particle volume and $(<800 \mathrm{~nm})$ an optically derived $\mathrm{PM}_{2.5}$ soot concentration yielded measures of determination $\left(R^{2}\right)$ between 0.76 and 0.85 , suggesting a strong association between the non-volatile particle residues and soot.

The meteorological analysis involved a separation of the data set according to local wind direction, the mixed layer height, and back trajectories. The prime result was that the height of the planetary boundary layer played the most important role on the particle number concentrations in Augsburg. The highest particle number concentrations $>30 \mathrm{~nm}$ were associated with the most stable inversion situations, and, slightly surprisingly, not necessarily with air masses from the continental source regions of Eastern Europe. The importance of the mixing layer height found here confirms earlier studies of surface-measured particle mass concentrations in urban areas (e.g. Schäfer et al., 2006).

It is a main conclusion that the particle size distribution in the urban atmosphere of a continental city like Augsburg is shaped by a combination of relatively few effects. The vertical stability of the atmosphere, particularly, proved to be a very influential factor, more important for instance than the local or large-scale wind direction. Our results are valuable background information for future epidemiological studies and particle exposure assessments. 
(a)

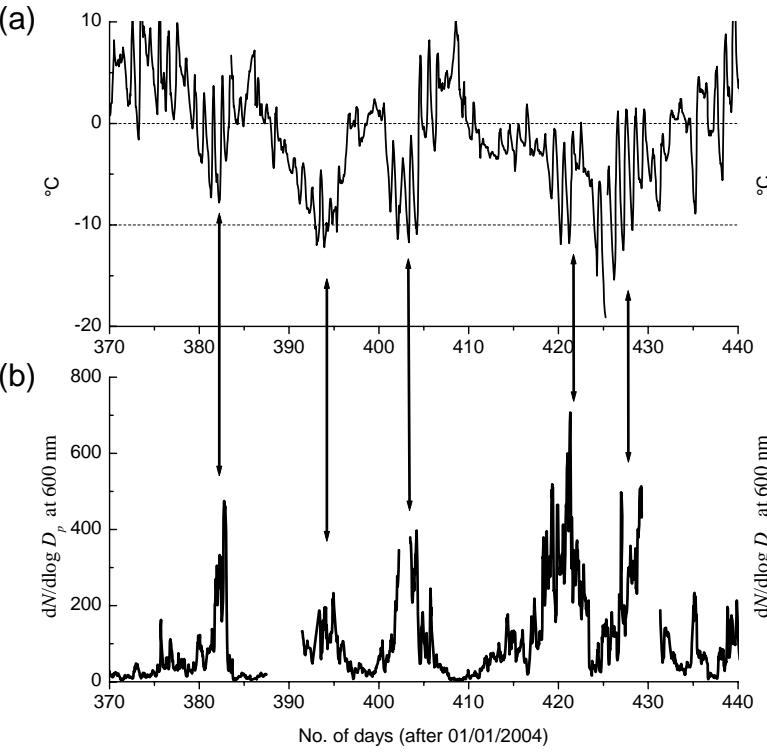

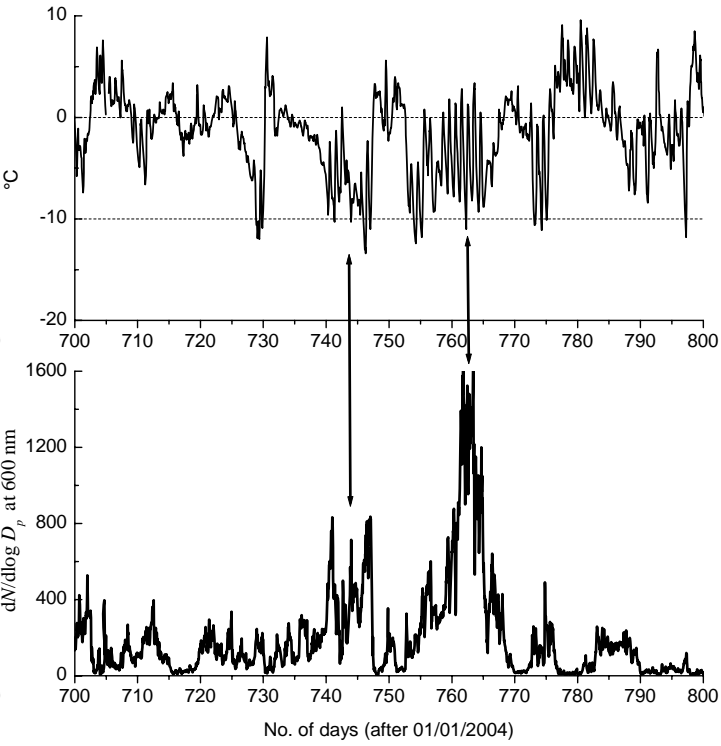

Fig. A1. Time history of ambient temperature (a) and the number concentration of $600 \mathrm{~nm}$-particles. The left-hand and right-hand graphs correspond to the winters 2004/2005 and 2005/2006, respectively. Several episodes that show simultaneous high particle concentrations and low temperatures are marked by arrows.

\section{Appendix A}

\section{Detailed time history}

Figure A1 shows the detailed time histories of ambient temperature and the number concentration of $600 \mathrm{~nm}$-particles in Augsburg for the two winters 2004/2005 and 2005/2006, respectively. The seven marked episodes are discussed in Sect. 3.1.2.

Acknowledgements. We acknowledge Hans Kaufmann (FH Augsburg) for providing the wind measurements at the roof-top station. Back trajectories were calculated on the NOAA ARL Ready Website using the HYSPLIT (HYbrid Single-Particle Lagrangian Integrated Trajectory) Model (Draxler, R. R. and Hess, G. D., 2003, NOAA Air Resources Laboratory, Silver Spring, MD, USA). Radiosoundings at Oberschleissheim were made by the German Weather Service DWD and accessed through the University of Wyoming website (http://weather.uwyo.edu/upperair/). We thank Christa Engler for characterising the particle transmission of the thermodenuder. Part of the data evaluation was supported by the European Integrated project on Aerosol Cloud Climate and Air Quality Interactions (EUCAARI), coordinated by the University of Helsinki, Finland.

Edited by: V.-M. Kerminen

\section{References}

Aalto, P., Hämeri, K., Paatero, P., et al.: Aerosol particle number concentration measurements in five European cities using TSI3022 Condensation Particle Counter over three-year period during health effects of air pollution on susceptible subpopulations, J. Air Waste Manage. Assoc., 55, 1064-1076, 2005.

An, W., Pathak, R., Lee, B., et al.: Aerosol volatility measurement using an improved thermodenuder: Application to secondary organic aerosol, J. Aerosol Sci., 38, 305-314, 2007.

Birmili, W., Stratmann, F., and Wiedensohler, A.: Design of a DMA-based size spectrometer for a large particle size range and stable operation, J. Aerosol Sci., 30, 549-553, 1999.

Birmili, W., Wiedensohler, A., Heintzenberg, J., and Lehmann, K.: Atmospheric particle number size distribution in Central Europe: Statistical relations to air masses and meteorology, J. Geophys. Res., 106(D23), 32005-32018, 2001.

Birmili, W., Alaviippola, B., Hinneburg, D., Knoth, O., Tuch, T., Borken-Kleefeld, J., and Schacht, A.: Dispersion of trafficrelated exhaust particles near the Berlin urban motorway estimation of fleet emission factors, Atmos. Chem. Phys., 9, 23552374, doi:10.5194/acp-9-2355-2009, 2009a.

Birmili, W., Weinhold, S., Nordmann, S., Wiedensohler, A., Spindler, G. et al.: Atmospheric aerosol measurements in the German Ultrafine Aerosol Network (GUAN): Part 1 - soot and particle number size distributions, Gefahrst. Reinh. Luft, 69(4), 137-145, 2009b.

Birmili, W., Schwirn, K., Nowak, A., et al.: Hygroscopic growth of atmospheric particle number size distributions in the Finnish boreal forest region, Bor. Env. Res., 14, 458-480, 2009c.

Burtscher, H., Baltensperger, U., Bukowiecki, N., et al.: Separation of volatile and non-volatile aerosol fractions by thermodesorption: instrumental development and applications, J. Aerosol Sci., 32, 427-442, 2001. 
Charron, A. and Harrison, R. M.: Primary particle formation from vehicle emissions during exhaust dilution in the roadside atmosphere, Atmos. Environ., 37, 4109-4119, 2003.

Costabile, F., Birmili, W., Klose, S., Tuch, T., Wehner, B., Wiedensohler, A., Franck, U., König, K., and Sonntag, A.: Spatiotemporal variability and principal components of the particle number size distribution in an urban atmosphere, Atmos. Chem. Phys., 9, 3163-3195, doi:10.5194/acp-9-3163-2009, 2009.

Clarke, A. D.: A thermo-optic technique for in-situ analysis of sizeresolved aerosol physiochemistry, Atmos. Environ., Part A, 25, 635-644, 1991.

Cyrys, J., Stölzel, M., Kreyling, W. G., et al.: Sources and elemental composition of ambient particles in Erfurt, Germany, Sci. Total Environ., 305, 143-156, 2003.

Cyrys, J., Pitz, M., Heinrich, J., et al.: Spatial and temporal variation of particle number concentration in Augsburg, Germany, Sci. Total Environ., 401, 168-175, 2008.

Draxler, R. and Hess, G.: Description of the HYSPLIT4 modeling system, NOAA Technical Memorandum, ERL, ARL-224, 2004.

Ebelt, S., Cyrys, J., Brauer, S., et al.: Air Quality in Postunification Erfurt, East Germany: Associating changes in pollutant concentrations with changes in emissions, Environ. Health Persp., 109, 325-333, 2001.

EC: Council Directive 1999/30/EC, of 22 April 1999: Limit values for sulphur dioxide, nitrogen dioxide and oxides of nitrogen, particulate matter and lead in ambient air (The First Daughter Directive), 1999.

Ehn, M., Petjä, T., Birmili, W., Junninen, H., Aalto, P., and Kulmala, M.: Non-volatile residuals of newly formed atmospheric particles in the boreal forest, Atmos. Chem. Phys., 7, 677-684, doi:10.5194/acp-7-677-2007, 2007.

Engler, C., Rose, D., Wehner, B., Wiedensohler, A., Brüggemann, E., Gnauk, T., Spindler, G., Tuch, T., and Birmili, W.: Size distributions of non-volatile particle residuals $(D p<800 \mathrm{~nm})$ at a rural site in Germany and relation to air mass origin, Atmos. Chem. Phys., 7, 5785-5802, doi:10.5194/acp-7-5785-2007, 2007.

Fierz, M., Vernooij, M., and Burtscher, H.: An improved low-flow thermodenuder, J. Aerosol Sci., 38, 1163-1168, 2007.

Hasegawa, S., Hirabayashi, M., Kobayashi, S., et al.: Size distribution and characterization of ultrafine particles in roadside atmosphere, J. Environ. Sci. Heal. A., 39, 2671-2690, 2004.

HEI: Understanding the health effects of components of the particulate matter mix: progress and next steps, Tech. Rep. 4, Health Effects Institute, Boston, MA, 2002.

Heintzenberg, J., Birmili, W., Wiedensohler, A., Nowak, A., and Tuch, T.: Structure, variability and persistence of the submicrometre marine aerosol, Tellus, 56B, 357-367, 2004.

Hitchins, J., Morawska, L., Wolff, R., and Gilbert, D.: Concentrations of submicrometre particles from vehicle emissions near a major road, Atmos. Environ., 34, 51-59, 2000.

Holle, R., Happich, M., Löwel, H., and Wichmann, H.: KORA - A Research platform for population based health research, Gesundheitswesen, 67, S19-S25, 2005.

Holzworth, C. G.: Estimates of mean maximum mixing depths in the contiguous United States, Mon. Weather Rev., 92, 235-242, 1964.

Huffman, J., Ziemann, P., Jayne, J., Worsnop, D., and Jimenez, J.: Development and characterization of a fast-stepping/scanning thermodenuder for chemically-resolved aerosol volatility mea- surements, Aerosol Sci. Technol., 42, 395-407, 2008.

Hussein, T., Puustinen, A., Aalto, P. P., Mäkelä, J. M., Hämeri, K., and Kulmala, M.: Urban aerosol number size distributions, Atmos. Chem. Phys., 4, 391-411, doi:10.5194/acp-4-391-2004, 2004.

Imhof, D., Weingartner, E., Ordóñez, C., et al.: Real-world emission factors of fine and ultrafine aerosol particles for different traffic situations in Switzerland, Environ. Sci. Technol., 39, 8341-8350, 2005.

Johnson, G. R., Ristovski, Z., and Morawska, L.: Method for measuring the hygroscopic behaviour of lower volatility fractions in an internally mixed aerosol, J. Aerosol Sci., 35, 443455, 2004.

Kalberer, M., Paulsen, D., Sax, M., et al.: Identification of polymers as major components of atmospheric organic aerosols, Science, 303, 1659-1662, 2004.

Ketzel, M., Wahlin, P., Berkowicz, R., and Palmgren, F.: Particle and trace gas emission factors under urban driving conditions in Copenhagen based on street and roof-level observations, Atmos. Environ., 37, 2735-2749, 2003.

Ketzel, M., Wåhlin, P., Kristensson, A., Swietlicki, E., Berkowicz, R., Nielsen, O. J., and Palmgren, F.: Particle size distribution and particle mass measurements at urban,near-city and rural level in the Copenhagen area and Southern Sweden, Atmos. Chem. Phys., 4, 281-292, doi:10.5194/acp-4-281-2004, 2004.

Kittelson, D., Watts, W., and Johnson, J.: On-road and laboratory evaluation of combustion aerosols - Part 1: Summary of diesel engine results, J. Aerosol Sci., 37, 913-930, 2006.

Kreidenweis, S. M., McInnes, L. M., and Brechtel, F. J.: Observations of aerosol volatility and elemental composition at Macquarie Island during the First Aerosol Characterization Experiment (ACE1), J. Geophys. Res., 103, 16511-16524, 1998.

Kreyling, W. and Scheuch, G.: Clearance of particles deposited in the lungs, in Particle-Lung Interactions, edited by P. Gehr and J. Heyder, 323-376, Marcel Dekker, New York, 2000.

Kreyling, W., Tuch, T., Peters, A., et al.: Diverging long-term trends in ambient urban particle mass and number concentrations associated with emission changes caused by the German unifcation, Atmos. Environ., 37, 3841-3848, 2003.

Kukkonen, J., Pohjola, M., Sokhi, R., et al.: Analysis and evaluation of local scale PM10 air pollution episodes in four European cities: Helsinki, London, Milan and Oslo, Atmos. Environ., 39, 2759-2773, 2005.

Kulmala, M., Vehkamäki, H., Petäjä, T., et al.: Formation and growth rates of ultrafine atmospheric particles: A review of observations, J. Aerosol Sci., 35, 143-176, 2004.

Möller, W., Felten, K., Sommerer, K., et al.: Deposition, retention, and translocation of ultrafine particles from the central airways and lung periphery, Am. J. Resp. Crit. Care Med., 177, 426-432, 2008.

Ntziachristos, L., Mamakos, A., Samaras, Z., et al.: Overview of the European Particulates project on the characterization of exhaust particulate emissions from road vehicles: Results for light-duty vehicles, SAE Trans., 113, 1354-1373, 2004.

Oberdörster, G., Oberdörster, G., and Oberdörster, G.: Nanotoxicology: an emerging discipline evolving from studies of ultrafine particles, Environ. Health Persp., 113, 823-839, 2005.

Peters, A., von Klot, S., Heier, M., et al.: Particulate air pollution and nonfatal cardiac events. Part I. air pollution, personal activities, and onset of myocardial infarction in a case-crossover study, 
HEI Research Report, 124, 1-82, 2005.

Petzold, A. and Schönlinner, M.: Multi-angle absorption photometry - a new method for the measurement of aerosol light absorption and atmospheric black carbon, J. Aerosol Sci., 35, 421-441, 2004.

Petzold, A., Schloesser, H., Sheridan, P. J., Arnott, W. P., Ogren, J. A., and Virkkula, A.: Evaluation of multiangle absorption photometry for measuring aerosol light absorption, Aerosol Sci. Technol., 39, 40-51, 2005.

Philippin, S., Wiedensohler, A., and Stratmann, F.: Measurements of non-volatile fractions of pollution aerosols with an eight-tube volatility tandem differential mobility analyzer (VTDMA-8), J. Aerosol Sci., 35, 185-203, 2004.

Pinnick, R. G., Jennings, S. G., and Fernandez, G.: Volatility of aerosols in the arid southwestern United States, J. Atmos. Sci., 44, 562-576, 1987.

Pitz, M., Schmid, O., Heinrich, J., et al.: Seasonal and diurnal variation of PM2.5 apparent particle density in urban air in Augsburg, Germany, Environ. Sci. Technol., 42, 5087-5093, 2008a.

Pitz, M., Birmili, W., Schmid, O., Peters, A., and Cyrys, J.: Quality assurance of aerosol particle size distribution measurements at an urban air pollution monitoring station in Augsburg, Germany, J. Environ. Mon., 10, 1017-1024, 2008b.

Pope, C. and Dockery, D.: Health effects of fine particulate air pollution: lines that connect, J. Air Waste Manage. Assoc., 56, 709742,2006

Rose, D., Wehner, B., Ketzel, M., Engler, C., Voigtländer, J., Tuch, T., and Wiedensohler, A.: Atmospheric number size distributions of soot particles and estimation of emission factors, Atmos. Chem. Phys., 6, 1021-1031, doi:10.5194/acp-6-1021-2006, 2006.

Rosenbohm, E., Vogt, R., Scheer, V., et al.: Particulate size distributions and mass measured at a motorway during the BAB II campaign, Atmos. Environ., 39, 5696-5709, 2005.

Ruuskanen, J., Tuch, T., and ten Brink, H.: Concentrations of ultrafine, fine and $\mathrm{PM}_{2.5}$ particles in three European cities, Atmos. Environ., 35, 3729-3738, 2001.

Sakurai, H., Park, K., McMurry, P., et al.: Size-dependent mixing characteristics of volatile and nonvolatile components in diesel exhaust aerosols, Environ. Sci. Technol., 37, 5487-5495, 2003.

Schäfer, K., Emeis, S., Hoffmann, H., and Jahn, C.: Influence of mixing layer height upon air pollution in urban and sub-urban areas, Meteorolog. Z., 15, 647-658, 2006.

Schmid, O., Eimer, B., Hagen, D., et al.: Investigation of volatility methods for measuring aqueous sulfuric acid on mixed aerosols, Aerosol Sci. Technol., 36, 877-889, 2002.

Schwarze, P., Ovrevik, J., and Lag, M.: Particulate matter properties and health effects: Consistency of epidemiological and toxicological studies, Hum. Exp. Toxicol., 25, 559-579, 2006.

Smith, M. H. and O'Dowd C. D.: Observations of accumulation mode aerosol composition and soot carbon concentrations by means of a high-temperature volatility technique, J. Geophys. Res., 101, 19583-19591, 1996.

Sioutas, C., Delfino, R., and Singh, M.: Exposure assessment for atmospheric ultrafine particles (UFPs) and implications in epidemiologic research, Environ. Health Persp., 113, 947-955, 2005.

Stanier, C., Khlystov, A., and Pandis, S.: Ambient aerosol size distributions and number concentrations measured during the Pitts- burgh air quality study, Atmos. Environ., 38, 3275-3284, 2004.

Stull, R.: An introduction to boundary layer meteorology, Reidel Publishing, Dordrecht, 1988.

Sunder Raman, R., Hopke, P. K., and Holsen T. M.: Carbonaceous aerosol at two rural locations in New York State: Characterization and behavior, J. Geophys. Res., 113, D12202, doi:10.1029/2007JD009281, 2008.

Thorpe, A. and Harrison, R. M.: Sources and properties of nonexhaust particulate matter from road traffic: A review, Sci. Total Environ., 400, 270-282, 2008.

Tunved, P., Hansson, H.-C., Kulmala, M., Aalto, P., Viisanen, Y., Karlsson, H., Kristensson, A., Swietlicki, E., Dal Maso, M., Ström, J., and Komppula, M.: One year boundary layer aerosol size distribution data from five nordic background stations, Atmos. Chem. Phys., 3, 2183-2205, 2003,

http://www.atmos-chem-phys.net/3/2183/2003/.

van Dingenen, R., Raes, F., Puteaud, J.-P., et al.: A European aerosol phenomenology-1: Physical characteristics of particulate matter at kerbside, urban, rural and background sites in Europe, Atmos. Environ., 38, 2561-2577, 2004.

Vester, B., Ebert, M., Barnert, E., et al.: Composition and mixing state of the urban background aerosol in the Rhein-Main area (Germany), Atmos. Environ., 41, 6102-6115, 2007.

Voigtländer, J., Tuch, T., Birmili, W., and Wiedensohler, A.: Correlation between traffic density and particle size distribution in a street canyon and the dependence on wind direction, Atmos. Chem. Phys., 6, 4275-4286, doi:10.5194/acp-6-4275-2006, 2006.

von Klot, S., Peters, A., Aalto, P. et al.: Ambient air pollution is associated with increased risk of hospital cardiac readmissions of myocardial infarction survivors in five European cities. Report of the Health Effects of Particles on Susceptible Subpopulations (HEAPSS) Study Group, Circulation, 112, 3073-3079, 2005.

Wehner, B., Birmili, W., Gnauk, T., and Wiedensohler, A.: Particle number size distributions in a street canyon and their transformation into the urban background: Measurements and a simple model study, Atmos. Environ., 36, 2215-2223, 2002a.

Wehner, B., Philippin, S., Wiedensohler, A., and Haudek, A.: Design and calibration of an improved thermodenuder to study the volatility fraction of aerosol particles, J. Aerosol Sci., 33, 10871093, 2002b.

Wehner, B. and Wiedensohler, A.: Long term measurements of submicrometer urban aerosols: statistical analysis for correlations with meteorological conditions and trace gases, Atmos. Chem. Phys., 3, 867-879, doi:10.5194/acp-3-867-2003, 2003.

Wehner, B., Petäjä, T., Boy, M., et al.: The contribution of sulfuric acid and non-volatile compounds on the growth of freshly formed atmospheric aerosols, Geophys. Res. Lett., 32, L17810, doi:10.1029/2005GL023827, 2005.

Wehner, B., Birmili, W., Ditas, F., Wu, Z., Hu, M., Liu, X., Mao, J., Sugimoto, N., and Wiedensohler, A.: Relationships between submicrometer particulate air pollution and air mass history in Beijing, China, 20042006, Atmos. Chem. Phys., 8, 6155-6168, doi:10.5194/acp-8-6155-2008, 2008.

WHO: Health Effects of Air Pollution Results from the WHO Project Systematic Review of Health Aspects of Air Pollution in Europe, Tech. Rep. E83080, World Health Organisation, Geneva, 2004. 
WHO: Health risks of particulate matter from long-range transboundary air pollution, joint WHO/Convention Task Force on the Health Aspects of Air Pollution, WHOLIS E88189, World Health Organisation, Regional Office for Europe, Bonn, 2006.

Wichmann, H.-E. and Peters, A.: Epidemiological evidence of the effects of ultrafine particle exposure, Philos. T. Roy. Soc. London, 358, 2751-2769, 2000.

Wichmann, H.-E., Cyrys, J., Stölzel, M., et al.: Sources and elemental composition of ambient particles in Erfurt, Germany, Ecomed Verlag, Landsberg am Lech, 2002.
Wigley, T. M. L, Smith, R. L., and Santer, B. D.: Anthropogenic influence on the autocorrelation structure of hemispheric-mean temperatures, Science, 282, 1676-1679, 1998.

Woo, K. S., Chen, D.-R., Pui, D. Y. H., and McMurry, P. H.: Measurements of Atlanta aerosol size distribution: Observation of ultrafine particle events, Aerosol Sci. Technol., 34(1), 75-87, 2001.

Zhu, Y., Hinds, W., Shen, S., and Sioutas, C.: Seasonal and spatial trends in fine particulate matter - seasonal trends of concentration and size distribution of ultrafine particles near major highways in Los Angeles, Aerosol Sci. Technol., 38, 5-13, 2004. 